\title{
DEFINING A GLASS COMPOSITION ENVELOPE FOR AN IMPURITY VARIABILITY STUDY TO SUPPORT PLUTONIUM DISPOSITION
}

K.M. Fox

E.N. Hoffman

T.B. Edwards

J.C. Marra

July 2007

Materials Science and Technology Savannah River National Laboratory Aiken, SC 29808

Prepared for the U.S. Department of Energy Under Contract Number DEAC09-96SR18500

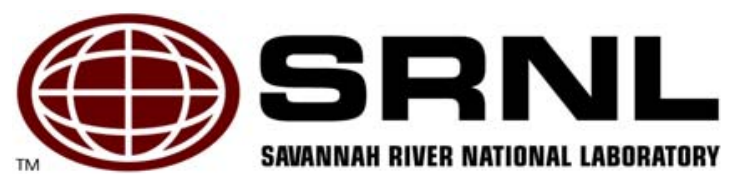


WSRC-STI-2007-00386

Revision 0

\section{DISCLAIMER}

This report was prepared by Washington Savannah River Company (WSRC) for the United States Department of Energy under Contract No. DE-AC09-96SR18500 and is an account of work performed under that contract. Neither the United States Department of Energy, nor WSRC, nor any of their employees makes any warranty, expressed or implied, or assumes any legal liability or responsibility for the accuracy, completeness, or usefulness, of any information, apparatus, or product or process disclosed herein or represents that its use will not infringe privately owned rights. Reference herein to any specific commercial product, process, or service by trademark, name, manufacturer or otherwise does not necessarily constitute or imply endorsement, recommendation, or favoring of same by WSRC or by the United States Government or any agency thereof. The views and opinions of the authors expressed herein do not necessarily state or reflect those of the United States Government or any agency thereof.

\section{Printed in the United States of America \\ Prepared For U.S. Department of Energy}

The Savannah River National Laboratory is operated for the U.S. Department of Energy by Washington Savannah River Company. 
Keywords: waste glass, variability study, Pu disposition

Retention: permanent

\section{DEFINING A GLASS COMPOSITION ENVELOPE FOR AN IMPURITY VARIABILITY STUDY TO SUPPORT PLUTONIUM DISPOSITION}

K.M. Fox

E.N. Hoffman

T.B. Edwards

J.C. Marra

July 2007

Materials Science and Technology Savannah River National Laboratory Aiken, SC 29808 


\section{REVIEWS AND APPROVALS}

\section{AUTHORS:}

K.M. Fox, Materials Science and Technology

Date

E.N. Hoffman, Materials Science and Technology

Date

T.B. Edwards, Statistical Consulting Section

Date

J.C. Marra, Materials Science and Technology

Date

\section{TECHNICAL REVIEWER:}

A.D. Cozzi, Process Science and Engineering

Date

\section{APPROVERS:}

G.T. Chandler, Manager, Materials Performance and Corrosion Technology

Date

N.C. Iyer, Director, Materials Science and Technology

Date

D.P. Eisele, Nuclear Materials Management Engineering

Date

R.H. Smith, Technology Manager

Date 


\section{EXECUTIVE SUMMARY}

This study focuses on the development of a composition envelope that describes the solubility of various impurities in the lanthanide borosilicate (LaBS) glass. A series of glass compositions was selected, fabricated and characterized in order to define this envelope. The selection of glass compositions, which is the focus of this report, was based on the projected types and concentrations of impurities expected in the plutonium feed stream. A limited amount of impurity data for the various plutonium sources is available and projections were made through analysis of the available information. These projections were used to define the glass compositions to be fabricated and tested.

The results of this glass selection process provided an array of glass compositions to be fabricated and characterized in the laboratory in order to evaluate the solubility of various impurity elements and their effects on crystallization and durability as measured by the Product Consistency Test (PCT). The majority of the glasses will be formulated with hafnium as a surrogate for plutonium to simplify laboratory experiments. Plutonium glass testing will also be implemented for select compositions to validate the results of the surrogate testing. The results of this variability testing will be discussed in a separate report that will provide data to validate the acceptability of the compositional envelope defined here and/or provide additional compositional constraints for the plutonium feed materials. 


\section{TABLE OF CONTENTS}

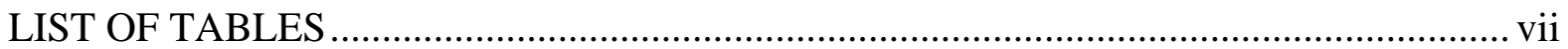

LIST OF abbreviations ............................................................................................. viii

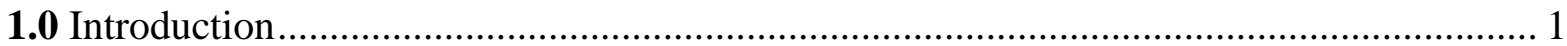

2.0 Development of the Impurity Test Matrix ..................................................................... 3

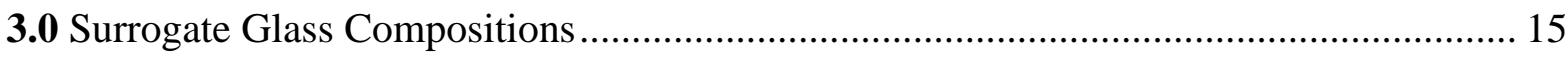

4.0 Selection of Impurities for Pu Glasses .................................................................... 18

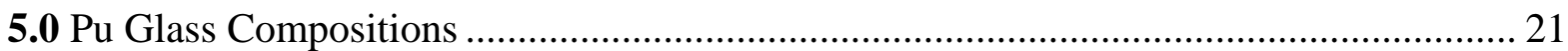

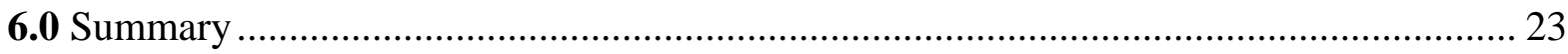

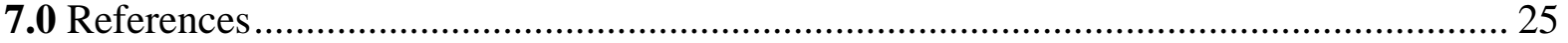

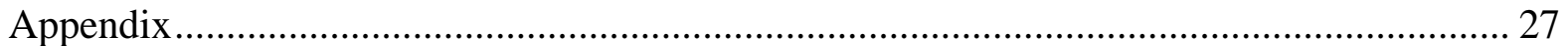




\section{LIST OF TABLES}

Table 2-1. Impurities and Their Possible Concentrations as Mass Fractions in the Feed 3

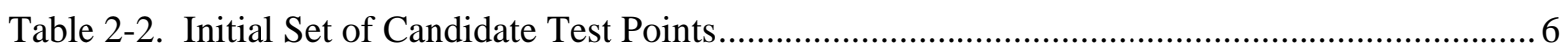

Table 2-3. Initial Set of Test Points with Identifiers ….................................................................. 8

Table 2-4. Impurities and Their Possible Concentrations as Mass Fractions in the Feed for an Inner Layer of Test Points ................................................................................................. 9

Table 2-5. An Inner-Layer of Test Points with Identifiers and with S, C, Pb, Se, and Cs Set to Zero

Table 2-6. An Inner-Layer of Test Points with Identifiers and with S, C, Pb, Se, and Cs Set to 0.0005 as Mass Fractions.

Table 2-7. Impurities and Their Possible Concentrations as Mass Fractions in the Feed for the Innermost Layer of Test Points

Table 2-8. Inner-Most Layer of Test Points Optimally Selected with Identifiers and with S, C, $\mathrm{Pb}$, Se, and Cs Set to 0.005 as Mass Fractions.

Table 2-9. Two Centroids with Identifiers Determined from the Other Design Points of the Test Matrix

Table 2-10. Five Test Points with Identifiers Selected to Cover a 0.04 Level (in mass fractions)

of Total Impurity in the Feed 12

Table 3-1. Composition of LaBS Frit X (in wt\% oxides). 15

Table 3-2. Target Compositions for the 60 Surrogate Glasses (in wt\%).......................................... 16

Table 5-1. Target Glass Compositions for the Pu Glasses (in wt\%). 21 


\section{LIST OF ABBREVIATIONS}

DOE

DOE-EM

HLW

LaBS

MFFF

MOX

MT

NMM

PIP

SRNL

VPWF

WSRC
Department of Energy

Department of Energy - Office of Environmental Management

High Level Waste

Lanthanide Borosilicate

Mixed Oxide Fuel Fabrication Facility

Mixed Oxide

Metric Tons

Nuclear Materials Management

Plutonium Immobilization Program

Savannah River National Laboratory

Vitrified Plutonium Waste Form

Washington Savannah River Company 
WSRC-STI-2007-00386

Revision 0

\subsection{Introduction}

In the aftermath of the Cold War, the United States has identified an excess of up to 50 metric tons (MT) of weapons-useable plutonium. The Department of Energy (DOE) was to construct both a Mixed Oxide Fuel Fabrication Facility (MFFF) and a Plutonium Immobilization Program (PIP) facility to disposition this material. In April 2002, DOE decided not to construct the PIP facility and to solely proceed with the construction of the MFFF facility with a focus only on the disposition of weapons-grade plutonium to meet the non-proliferation agreement between Russia and the United States. This action resulted in up to 13 metric tons of DOE-Office of Environmental Management (DOE-EM) owned, weapons usable, plutonium-bearing materials having no clear disposition path.

A vitrification technology utilizing a lanthanide borosilicate (LaBS) glass appears to be a viable option to disposition excess weapons-useable plutonium that is not suitable for processing into mixed oxide (MOX) fuel. A significant effort to develop a glass formulation and vitrification process to immobilize plutonium was completed in the mid-1990s to support the PIP. The LaBS glass formulation was found to be capable of immobilizing in excess of $10 \mathrm{wt} \% \mathrm{Pu}$ and to be very tolerant of the impurities accompanying the plutonium material streams. ${ }^{1,2}$ Thus, this waste form could be suitable for the disposition of plutonium owned by the DOE-EM that may not be well characterized and that may contain high levels of impurities. However, the relative tolerance of the glass composition to the various feed impurities needs to be studied.

The can-in-canister technology demonstrated in the $\mathrm{PIP}^{3,4}$ could be utilized to dispose of the vitrified plutonium in the federal radioactive waste repository. The can-in-canister technology involves placing small cans of the vitrified Pu form into a high level waste (HLW) glass canister fitted with a rack to hold the cans and then filling the canister with HLW glass to provide proliferation resistance. The completed assembly containing the plutonium glass and the HLW glass would be referred to as the Vitrified Plutonium Waste Form (VPWF).

This study focuses on the development of a composition envelope that describes the solubility of various impurities in the LaBS glass. To define this envelope, a series of glass compositions was selected, fabricated and characterized. The selection of glass compositions, which is the focus of this report, is based on the projected types and concentrations of impurities expected in the $\mathrm{Pu}$ feed stream. A limited amount of impurity data for the various Pu sources is available and projections can be made through analysis of the available information. These projections were used to define the test glass compositions.

The results of this glass selection process provide an array of glass compositions to be fabricated and characterized in the laboratory in order to evaluate the solubility of various impurity elements and their effects on crystallization. The majority of the glasses will be formulated with $\mathrm{Hf}$ as a surrogate for Pu on a mass basis to simplify laboratory experiments. Pu glass testing will be implemented for select compositions for comparison with the results of the surrogate testing. This work was initiated by an Nuclear Materials Management (NMM) Technical Task Request ${ }^{5}$ and is performed under a Savannah River National Laboratory (SRNL) Task Technical and Quality Assurance Plan. ${ }^{6}$ 
WSRC-STI-2007-00386

Revision 0

This page intentionally left blank. 
WSRC-STI-2007-00386

Revision 0

\subsection{Development of the Impurity Test Matrix}

A detailed analysis of the anticipated Pu feeds to be immobilized in waste glass has been provided by Moore and Allender. ${ }^{7}$ The projected impurity types and concentrations described in their report were used as the basis for defining the compositions of the glasses to be fabricated for this study.

The report projected the concentrations of more than 70 possible elements as impurities in the $\mathrm{Pu}$ feed. This list was reduced to seventeen elements based on several criteria. First, all of the elements with a best estimate maximum concentration of $18,000 \mu \mathrm{g} / \mathrm{g}$ and above were included. Silicon was removed from this group since it is a glass former (i.e., solubility of $\mathrm{Si}$ in the glass should not be an issue). Next, sulfur, carbon and lead were included since these elements are known to typically have low solubility in the LaBS glass. Finally, selenium and cesium were included again due to low solubility being expected for these elements in LaBS glass.

Table 2-1 lists the impurities that were chosen using these criteria. For each of the elements in this table, an interval of possible concentrations is given. This interval represents the possible concentration of the indicated element as an impurity in the feed. The lower limits were defined by rounding the best estimate concentration for $50 \%$ of the projected feeds to either zero or, in the case of chlorine, to 5,000 $\mu \mathrm{g} / \mathrm{g}$. The upper limits were defined by the greater of either the best estimate maximum concentration or the best estimate concentration for $98 \%$ of the projected feeds. These values were rounded to the nearest thousand $\mu \mathrm{g} / \mathrm{g}$. The concentration values were then converted to mass fractions of the Pu feed, as listed in Table 2-1.

Table 2-1. Impurities and Their Possible Concentrations as Mass Fractions in the Feed

\begin{tabular}{|c|c|c||}
\hline Element & $\begin{array}{c}\text { Lower } \\
\text { Limit }\end{array}$ & $\begin{array}{c}\text { Upper } \\
\text { Limit }\end{array}$ \\
\hline $\mathrm{Cl}$ & 0.05 & 0.35 \\
\hline $\mathrm{Ta}$ & 0 & 0.315 \\
\hline $\mathrm{Mg}$ & 0 & 0.35 \\
\hline $\mathrm{K}$ & 0 & 0.11 \\
\hline $\mathrm{Fe}$ & 0 & 0.08 \\
\hline $\mathrm{Na}$ & 0 & 0.096 \\
\hline $\mathrm{F}$ & 0 & 0.195 \\
\hline $\mathrm{Ca}$ & 0 & 0.048 \\
\hline $\mathrm{Ga}$ & 0 & 0.09 \\
\hline $\mathrm{Ni}$ & 0 & 0.04 \\
\hline $\mathrm{Cr}$ & 0 & 0.038 \\
\hline $\mathrm{Cu}$ & 0 & 0.02 \\
\hline $\mathrm{S}$ & 0 & 0.005 \\
\hline $\mathrm{C}$ & 0 & 0.005 \\
\hline $\mathrm{Pb}$ & 0 & 0.006 \\
\hline $\mathrm{Se}$ & 0 & 0.005 \\
\hline $\mathrm{Cs}$ & 0 & 0.005 \\
\hline
\end{tabular}

The chemical form of each of these impurity elements in the feed was not necessarily known, but there were some restrictions that were imposed on the approach used in developing the test matrix for this study. The first restriction imposed was a constraint on the overall mass of impurities in 
the feed. Moore and Allender provide total impurity concentration data for 2200 containers of the anticipated Pu feed based on Prompt Gamma Analysis and chemical estimates from laboratory samples. ${ }^{7}$ Using these data, the total mass of the impurities was set to $35 \%$ of the overall Pu feed stream. This value was chosen to represent a worst case impurity concentration based on the data provided by Moore and Allender. Thus, on a mass basis, a design point for the study had to satisfy the constraint that the sum of the mass fractions of all of the impurities of that design point had to add to 0.35 .

An additional restriction on the composition of the impurities making up a design point was required to address the issue of charge balance for that design point. If each of the impurities of Table 2-1 were converted to an oxide as a result of the vitrification process and if the feed were batched in these oxides to introduce the appropriate concentrations of all of the elements of Table 2-1, then there would be no need for a charge balance restriction. However, for $\mathrm{Cl}, \mathrm{F}$, and $\mathrm{S}$ this is not the case, and the batching of the impurities that involve one or more of these elements imposed a constraint of the amounts of other impurities of Table 2-1 that had to be present to provide a charge balance for the impurity concentration.

While the composition of each impurity design point was pursued in mass fractions, the charge balance restrictions applicable for impurity species involving $\mathrm{Cl}, \mathrm{F}$, and $\mathrm{S}$ were best expressed in mole fractions as given by the inequalities in Equations 1-4:

Equation 1.

$\frac{-1 \times \mathrm{Cl}}{35.453}+\frac{1 \times \mathrm{K}}{39.102}+\frac{1 \times \mathrm{Na}}{22.9898}+\frac{2 \times \mathrm{Pb}}{207.19}+\frac{1 \times \mathrm{Cs}}{132.905} \geq 0.001$

Equation 2.

$\frac{2 \times \mathrm{Mg}}{24.305}+\frac{1 \times \mathrm{K}}{39.102}+\frac{1 \times \mathrm{Na}}{22.9898}+\frac{-1 \times \mathrm{F}}{18.9984}+\frac{2 \times \mathrm{Pb}}{207.19}+\frac{1 \times \mathrm{Cs}}{132.905} \geq 0.001$

Equation 3.

$\frac{2 \times \mathrm{Na}}{22.9898}+\frac{-1 \times \mathrm{S}}{32.06} \geq 0.001$

Equation 4.

$\frac{-1 \times \mathrm{Cl}}{35.453}+\frac{2 \times \mathrm{Mg}}{24.305}+\frac{1 \times \mathrm{K}}{39.102}+\frac{3 \times \mathrm{Fe}}{55.847}+\frac{1 \times \mathrm{Na}}{22.9898}+\frac{-1 \times \mathrm{F}}{18.9984}+\frac{2 \times \mathrm{Pb}}{207.19}+\frac{-1 \times \mathrm{S}}{32.06}+\frac{1 \times \mathrm{Cs}}{132.905} \geq 0.003$

where the elements indicated in these equations are at concentrations expressed as mass fractions. Each of these equations was expressed as an inequality because any cation needed at concentrations greater than those supported by their Cl, F, and S species could be batched in the feed as an oxide. The cations that appear in each of the inequalities are those whose compounds for the active anion are considered to be amenable to the batching process (i.e., chemicals that could be safely handled in the laboratory). 
The constitution of a feasible design point for this impurity study can now be defined as a combination of the impurities of Table 2-1 in which the mass fraction of each impurity is within its interval of Table 2-1, the sum of the mass fractions equals 0.35 , and the mass fractions satisfy the inequalities given by Equation 1 through Equation 4. Equation 4 was added to ensure that the concentrations of the cation species that are common to two or more of the inequalities are not counted more than once in satisfying Equation 1 through Equation 3. The problem of finding these feasible combinations may be considered as a mixture problem. ${ }^{8}$ Statistical software such as JMP Version 6.0.2 is available to assist in working with such problems. ${ }^{9}$

One of the tools provided by JMP is its Custom Design routine within its Design of Experiments platform. ${ }^{10}$ This routine allows the user to specify a mixture problem in a framework such as that described above: a list of mixture components, their intervals of possible values, the value that the total of their concentrations must equal, and one or more linear constraints that the concentration values must satisfy. With the problem defined in such a manner, the user is then allowed to provide JMP with a model of interest, e.g., a model involving linear effects for each of the mixture component such as the one given by Equation 5, which serves as the basis for optimizing the experimental design.

\section{Equation 5.}

$$
\begin{gathered}
\mathrm{y}=\mathrm{a}_{1} \times \mathrm{Cl}+\mathrm{a}_{2} \times \mathrm{Ta}+\mathrm{a}_{3} \times \mathrm{Mg}+\mathrm{a}_{4} \times \mathrm{K}+\mathrm{a}_{5} \times \mathrm{Fe}+\mathrm{a}_{6} \times \mathrm{Na}+\mathrm{a}_{7} \times \mathrm{F}+\mathrm{a}_{8} \times \mathrm{Ca}+\mathrm{a}_{9} \times \mathrm{Ga}+ \\
\mathrm{a}_{10} \times \mathrm{Ni}+\mathrm{a}_{11} \times \mathrm{Cr}+\mathrm{a}_{12} \times \mathrm{Cu}+\mathrm{a}_{13} \times \mathrm{S}+\mathrm{a}_{14} \times \mathrm{C}+\mathrm{a}_{15} \times \mathrm{Pb}+\mathrm{a}_{16} \times \mathrm{Se}+\mathrm{a}_{17} \times \mathrm{Cs}
\end{gathered}
$$

In Equation 5, the solubility outcome for the experiment (all of the impurities were found to be soluble in the glass versus one or more of the impurities were found not to be soluble in the glass) may be considered as the response variable, $y$, and an optimal design may be generated using the routines of JMP to support the fitting of this model (i.e., estimating the $a_{i}$ 's, $i=1,2 ., \ldots 17$, of Equation 5). While fitting such a model is not of interest in this study, following this approach does provide a sound basis for selecting combinations of impurities for study.

There are several options available to the user in performing this optimization. One of the options is that the user can specify the target sum for the mixture. In this case, the sum of the impurities was specified in JMP as 0.35 on a mass fraction basis. JMP also provides the user with a choice of optimality criteria; for this situation the D-optimality criterion (a detailed description of the available criteria is available elsewhere ${ }^{10}$ ) was selected to serve as the basis for optimizing the test matrix. Ten different starting conditions were also selected to drive the optimization process. Finally, the minimum number of points (i.e., 17 - one for each of the $a_{i}$ terms in Equation 5) was specified as the desired number for the test matrix. Using this framework, the test matrix in Table 2-2 was generated by JMP. 
Table 2-2. Initial Set of Candidate Test Points

\begin{tabular}{|c|c|c|c|c|c|c|c|c|c|c|c|c|c|c|c|c|}
\hline $\mathrm{Cl}$ & Ta & $\mathrm{Mg}$ & $\mathrm{K}$ & $\mathrm{Fe}$ & $\mathrm{Na}$ & $\mathrm{F}$ & $\mathrm{Ca}$ & $\mathrm{Ga}$ & $\mathrm{Ni}$ & $\mathrm{Cr}$ & $\mathrm{Cu}$ & $S$ & $\mathrm{C}$ & $\mathrm{Pb}$ & Se & Cs \\
\hline 0.05000 & 0.00000 & 0.02100 & 0.00000 & 0.08000 & 0.09600 & 0.00000 & 0.04800 & 0.00000 & 0.04000 & 0.00000 & 0.00000 & 0.00500 & 0.00500 & 0.00000 & 0.00000 & 0.00500 \\
\hline 0.05000 & 0.00000 & 0.04700 & 11000 & 0.00000 & 0.00000 & 0.00000 & 0.04800 & 0.09000 & 0.00000 & 0.00000 & 0.00000 & 0.00000 & 0.00000 & 0.00000 & 0.00000 & 0.00500 \\
\hline 0.05000 & 0.00000 & 0.01990 & 0.00188 & 0.02674 & 0.02121 & 0.05032 & 0.00000 & 0.09000 & 0.04000 & 0.03800 & 0.00000 & 0.00500 & 0.00000 & 0.00000 & 0.00500 & 0.00195 \\
\hline 0.05166 & 0.07054 & 0.01130 & 0.03236 & 0.01146 & 0.06209 & 0.02162 & 0.00153 & 0.05043 & 0.00846 & 0.00975 & 0.01013 & 0.00154 & 0.00000 & 0.00112 & 0.00101 & 0.00500 \\
\hline 0.05580 & 0.02200 & 0.01577 & 0.01523 & 0.01871 & 0.04634 & 0.05816 & 0.01376 & 0.06870 & 0.00594 & 0.00177 & 0.01509 & 0.00500 & 0.00214 & 0.00487 & 0.00075 & 0.00000 \\
\hline 0.05753 & 0.02244 & 0.09160 & 0.00117 & 0.01813 & 0.02741 & 0.03368 & 0.01093 & 0.02738 & 0.01659 & 0.02637 & 0.01055 & 0.00000 & 0.00000 & 0.00310 & 0.00316 & 0.00000 \\
\hline 0.05825 & 0.01066 & 0.03730 & 0.09674 & 0.05882 & 0.04126 & & 0.00376 & 0.00337 & 0.00148 & 0.01192 & 0.00040 & 0.00500 & 0.00000 & 0.00000 & 0.00500 & 0.00000 \\
\hline 0.06425 & 0.04717 & & & & & & 0.00522 & & & & & 0.00380 & 0.00426 & 0.00000 & 0.00000 & 0.00000 \\
\hline 0.06427 & 0.00170 & 0.07963 & 0.04317 & 0.00132 & 0.01728 & 0.02632 & 0.00835 & 0.05680 & 0.00672 & 0.01959 & 0.00360 & 0.00500 & 0.00500 & 0.00600 & 0.00025 & 0.00500 \\
\hline 0.07099 & 0.00939 & 0.03613 & 0.00203 & 0.04624 & 0.03733 & 0.08211 & 0.02416 & 0.00181 & 0.00382 & 0.02499 & 0.00000 & 0.00000 & 0.00500 & 0.00100 & 0.00000 & 0.00500 \\
\hline 0.07183 & 0.05659 & 0.03366 & 0.04275 & 0.01402 & 0.00893 & 0.00500 & 0.02485 & 0.02841 & 0.02976 & 0.01819 & 0.00000 & 0.00000 & 0.00500 & 0.00600 & 0.00500 & 0.00000 \\
\hline 0.07196 & 0.01238 & 0.04211 & 0.01299 & 0.00185 & 0.06642 & 0.06786 & 0.03093 & 0.01385 & 0.00554 & 0.01619 & 0.00086 & 0.00000 & 0.00500 & 0.00000 & 0.00206 & 0.00000 \\
\hline 0.09268 & 0.01462 & 0.00375 & 0.06585 & 0.02993 & 0.03288 & 0.00299 & 0.00630 & 0.04108 & 0.02076 & 0.00996 & 0.01673 & 0.00142 & 0.00005 & 0.00600 & 0.00000 & 0.00500 \\
\hline 0.10014 & 0.07315 & 0.02094 & 0.02190 & 0.02481 & 0.02320 & 0.00612 & 0.00119 & 0.05009 & 0.01898 & 0.00071 & 0.00758 & 0.00000 & 0.00120 & 0.00000 & 0.00000 & 0.00000 \\
\hline 0.11512 & 0.05532 & 0.05847 & 0.00434 & 0.00543 & 0.00258 & 0.03543 & 0.03668 & 0.00608 & 0.01364 & 0.00125 & 0.00051 & 0.00500 & 0.00000 & 0.00015 & 0.00500 & 0.00500 \\
\hline 0.11617 & 0.00372 & 0.03592 & 0.02218 & 0.04363 & 0.01294 & 0.00358 & 0.03605 & 0.02046 & 0.00044 & 0.02247 & 0.01597 & 0.00104 & 0.00500 & 0.00042 & 0.00500 & 0.00500 \\
\hline 0.14175 & 0.01987 & 0.02391 & 0.02561 & 0.02343 & 0.00530 & 0.00224 & 0.04446 & 0.01409 & 0.00775 & 0.02579 & 0.00735 & 0.00362 & 0.00000 & 0.00483 & 0.00000 & 0.00000 \\
\hline
\end{tabular}


A review of the compositions of Table 2-2 indicated one other problem that had to be addressed. There was a need to ensure that no impurity with a positive concentration in a design point had a concentration less than 0.005 on a mass fraction basis. This was due to the fact that batching quantities less than 0.005 was deemed to be impractical. This led to the modification of some of the values in Table 2-2 to overcome this problem. The resulting compositions are provided in Table 2-3. 
Table 2-3. Initial Set of Test Points with Identifiers

\begin{tabular}{|c|c|c|c|c|c|c|c|c|c|c|c|c|c|c|c|c|c|}
\hline Test IDs & $\mathrm{Cl}$ & $\mathrm{Ta}$ & $\mathrm{Mg}$ & $\mathrm{K}$ & $\mathrm{Fe}$ & $\mathrm{Na}$ & $\mathrm{F}$ & Ca & $\mathrm{Ga}$ & $\mathrm{Ni}$ & $\mathrm{Cr}$ & $\mathrm{Cu}$ & $\mathrm{S}$ & C & $\mathrm{Pb}$ & $\mathrm{Se}$ & Cs \\
\hline $35-01$ & 0.050000 & 0.000000 & 0.021000 & 0.000000 & 0.080000 & 0.096000 & 0.000000 & 048000 & .000000 & .040000 & 0.000000 & 0.000000 & 0.005000 & 0.005000 & 0.000000 & 0.000000 & 0.005000 \\
\hline Pu35-02 & 0.050000 & 0.000000 & 0.047000 & 0.110000 & 0.000000 & 0.000000 & 0.000000 & .048000 & 0.090000 & 0.000000 & 0.000000 & 0.000000 & 0.000000 & 0.000000 & 0.000000 & 0.000000 & 0.005000 \\
\hline 135-03 & 0.050000 & 0.000000 & 0.019900 & 0.005000 & 0.026740 & 021210 & 844150 & 000000 & 090000 & 040000 & 0.038000 & 0.000000 & 0.005000 & 0.000000 & 0.000000 & 0.005000 & 0.005000 \\
\hline Pu35-04 & 0.050000 & 0.070540 & 0.011300 & 0.032360 & 0.011460 & 0.062090 & 0.008480 & 0.005000 & 0.050430 & 0.008460 & 0.009750 & 0.010130 & 0.005000 & 0.000000 & 0.005000 & 0.005000 & 0.005000 \\
\hline Pu35-05 & 0.055800 & 0.022000 & 0.015770 & 0.015230 & 0.018710 & 0.046340 & 0.047660 & 0.013760 & 0.068700 & 0.005940 & 0.005000 & 0.015090 & 0.005000 & 0.005000 & 0.005000 & 0.005000 & 0.000000 \\
\hline Pu35-06 & 0.057530 & 0.022440 & 0.091600 & 0.005000 & 0.018130 & 0.027410 & 0.026070 & 0.010930 & 0.027380 & 0.016590 & 0.026370 & 0.010550 & 0.000000 & 0.000000 & 0.005000 & 0.005000 & 0.000000 \\
\hline Pu35-07 & 0.050000 & 0.010660 & 0.037300 & 0.096740 & 0.058820 & 0.041260 & 0.013300 & 0.005000 & 0.005000 & 0.005000 & 0.011920 & 0.005000 & 0.005000 & 0.000000 & 0.000000 & 0.005000 & 0.000000 \\
\hline Pu35-08 & 0.064250 & 0.047170 & 0.051200 & 0.046740 & 0.005000 & 0.033240 & 0.017420 & 0.005220 & 0.020990 & 0.005050 & 0.025570 & 0.018150 & 0.005000 & 0.005000 & 0.000000 & 0.000000 & 0.000000 \\
\hline Pu35-09 & 0.064270 & 0.005000 & 0.079630 & 0.043170 & 0.005000 & 0.017280 & 0.013190 & 0.008350 & 0.056800 & 0.006720 & 0.019590 & 0.005000 & 0.005000 & 0.005000 & 0.006000 & 0.005000 & 0.005000 \\
\hline Pu35-10 & 0.059650 & 0.009390 & 0.036130 & 0.005000 & 0.046240 & 0.037330 & 0.082110 & 0.024160 & 0.005000 & 0.005000 & 0.024990 & 0.000000 & 0.000000 & 0.005000 & 0.005000 & 0.000000 & 0.005000 \\
\hline Pu35-11 & 0.071830 & 0.056600 & 0.033660 & 0.042750 & 0.014020 & 0.008930 & 0.005000 & 0.024850 & 0.028410 & 0.029760 & 0.018190 & 0.000000 & 0.000000 & 0.005000 & 0.006000 & 0.005000 & 0.000000 \\
\hline Pu35-12 & 0.061730 & 0.012380 & 0.042110 & 0.012990 & 0.005000 & 0.066420 & 0.067860 & 0.030930 & 0.013850 & 0.005540 & 0.016190 & 0.005000 & 0.000000 & 0.005000 & 0.000000 & 0.005000 & 0.000000 \\
\hline Pu35-13 & 0.080900 & 0.014620 & 0.005000 & 0.065850 & 0.029930 & 0.032880 & 0.005000 & 0.006300 & 0.041080 & 0.020760 & 0.009960 & 0.016730 & 0.005000 & 0.005000 & 0.006000 & 0.000000 & 0.005000 \\
\hline 135-14 & 0.088240 & 0.073150 & 0.020940 & 0.021900 & 0.024810 & 0.023200 & 0.006120 & 0.005000 & 0.050090 & 0.018980 & 0.005000 & 0.007580 & 0.000000 & 0.005000 & 0.000000 & 0.000000 & 0.000000 \\
\hline Pu35-15 & 0.098950 & 0.055320 & 0.058470 & 0.005000 & 0.005430 & 0.005000 & 0.035430 & 0.036680 & 0.006080 & 0.013640 & 0.005000 & 0.005000 & 0.005000 & 0.000000 & 0.005000 & 0.005000 & 0.005000 \\
\hline Pu35-16 & 0.100380 & 0.005000 & 0.035920 & 0.022180 & 0.043630 & 0.012940 & 0.005000 & 0.036050 & 0.020460 & 0.005000 & 0.022470 & 0.015970 & 0.005000 & 0.005000 & 0.005000 & 0.005000 & 0.005000 \\
\hline Pu35-17 & 0.132440 & 0.019870 & 0.023910 & 0.025610 & 0.023430 & 0.010300 & 0.005000 & 0.044460 & 0.014090 & 0.007750 & 0.025790 & 0.007350 & 0.005000 & 0.000000 & 0.005000 & 0.000000 & 0.000000 \\
\hline
\end{tabular}


To provide a more thorough coverage of the impurity space outlined by Table 2-1, additional design points were generated to complement the first set of 17 . The first addition to the design was made by following the same general approach as outlined above but with only the first 12 of the impurities in Table 2-1 active (i.e., S, C, Pb, Se, and Cs were set to zero) and with the intervals for the 12 active elements modified to the values of Table 2-4. This modification moved the concentrations of the elements active in the impurity within their original limits; thus, there was coverage of a more inner region of the impurity space.

Table 2-4. Impurities and Their Possible Concentrations as Mass Fractions in the Feed for an Inner Layer of Test Points

\begin{tabular}{||c|c|c||}
\hline \hline & \multicolumn{2}{|c|}{ Mass Fraction Interval } \\
\hline Element & $\begin{array}{c}\text { Lower } \\
\text { Limit }\end{array}$ & $\begin{array}{c}\text { Upper } \\
\text { Limit }\end{array}$ \\
\hline $\mathrm{Cl}$ & 0.05 & 0.27500 \\
\hline $\mathrm{Ta}$ & 0.01 & 0.23625 \\
\hline $\mathrm{Mg}$ & 0.01 & 0.26250 \\
\hline $\mathrm{K}$ & 0.01 & 0.08250 \\
\hline $\mathrm{Fe}$ & 0.01 & 0.06000 \\
\hline $\mathrm{Na}$ & 0.01 & 0.07200 \\
\hline $\mathrm{F}$ & 0.01 & 0.14625 \\
\hline $\mathrm{Ca}$ & 0.01 & 0.03600 \\
\hline $\mathrm{Ga}$ & 0.01 & 0.06750 \\
\hline $\mathrm{Ni}$ & 0.01 & 0.03000 \\
\hline $\mathrm{Cr}$ & 0.005 & 0.02850 \\
\hline $\mathrm{Cu}$ & 0.005 & 0.01500 \\
\hline
\end{tabular}

In this case, only 12 test points were optimally selected (this was due to a reduction in the number of terms in the model of Equation 5 - no terms were needed for S, C, Pb, Se, and Cs). The selected points are provided in Table 2-5.

Table 2-6 shows 12 additional design points with S, C, Pb, Se, and Cs each set to 0.005 on a mass fraction basis. The concentrations for the other 12 components for each of these test point were restricted to total of $0.35-(5 \times 0.005)=0.325$ on a mass fraction basis and were optimally selected using JMP. 
Table 2-5. An Inner-Layer of Test Points with Identifiers and with S, C, Pb, Se, and Cs Set to Zero

\begin{tabular}{|c|c|c|c|c|c|c|c|c|c|c|c|c|c|c|c|c|c|}
\hline Test IDs & $\mathrm{Cl}$ & $\mathrm{Ta}$ & $\mathrm{Mg}$ & $\mathrm{K}$ & $\mathrm{Fe}$ & $\mathrm{Na}$ & $\mathrm{F}$ & $\mathrm{Ca}$ & $\mathrm{Ga}$ & $\mathrm{Ni}$ & $\mathrm{Cr}$ & $\mathrm{Cu}$ & $\mathrm{S}$ & C & $\mathrm{Pb}$ & $\mathrm{Se}$ & Cs \\
\hline Pu35-18 & 0.06204 & 0.02602 & 0.02793 & 0.07553 & 0.01000 & 0.01427 & 0.04204 & 0.01000 & 0.05379 & 0.01000 & 0.01338 & 0.00500 & 0.00000 & 0.00000 & 0.00000 & 0.00000 & 0.00000 \\
\hline Pu35-19 & 0.05591 & 0.02098 & 0.03080 & 0.03335 & 0.01554 & 0.03914 & 0.06812 & 0.01154 & 0.02110 & 0.01003 & 0.02850 & 0.01500 & 0.00000 & 0.00000 & 0.00000 & 0.00000 & 0.00000 \\
\hline Pu35-20 & 0.05484 & 0.10579 & 0.02067 & 0.02857 & 0.02316 & 0.01845 & 0.02765 & 0.01909 & 0.01000 & 0.01461 & 0.01215 & 0.01500 & 0.00000 & 0.00000 & 0.00000 & 0.00000 & 0.00000 \\
\hline Pu35-21 & 0.09126 & 0.03718 & 0.02868 & 0.01401 & 0.03239 & 0.01675 & 0.04384 & 0.01540 & 0.03183 & 0.01000 & 0.01366 & 0.01500 & 0.00000 & 0.00000 & 0.00000 & 0.00000 & 0.00000 \\
\hline Pu35-22 & 0.15223 & 0.01000 & 0.01000 & 0.01977 & 0.01000 & 0.07200 & 0.01000 & 0.03600 & 0.01000 & 0.01000 & 0.00500 & 0.00500 & 0.00000 & 0.00000 & 0.00000 & 0.00000 & 0.00000 \\
\hline Pu35-23 & 0.05188 & 0.01555 & 0.09461 & 0.02063 & 0.01147 & 0.03547 & 0.02378 & 0.02633 & 0.01795 & 0.02600 & 0.01133 & 0.01500 & 0.00000 & 0.00000 & 0.00000 & 0.00000 & 0.00000 \\
\hline Pu35-24 & 0.05692 & 0.04231 & 0.03199 & 0.02353 & 0.03470 & 0.03729 & 0.02299 & 0.01735 & 0.02720 & 0.02856 & 0.02216 & 0.00500 & 0.00000 & 0.00000 & 0.00000 & 0.00000 & 0.00000 \\
\hline Pu35-25 & 0.05000 & 0.02224 & 0.03546 & 0.02070 & 0.01685 & 0.03988 & 0.07028 & 0.02537 & 0.04347 & 0.01576 & 0.00500 & 0.00500 & 0.00000 & 0.00000 & 0.00000 & 0.00000 & 0.00000 \\
\hline Pu35-26 & 0.05000 & 0.01000 & 0.04685 & 0.08250 & 0.05115 & 0.01000 & 0.01000 & 0.03600 & 0.01000 & 0.01000 & 0.02850 & 0.00500 & 0.00000 & 0.00000 & 0.00000 & 0.00000 & 0.00000 \\
\hline Pu35-27 & 0.05993 & 0.01248 & 0.08326 & 0.03292 & 0.04366 & 0.04911 & 0.01144 & 0.01661 & 0.01828 & 0.01000 & 0.00731 & 0.00500 & 0.00000 & 0.00000 & 0.00000 & 0.00000 & 0.00000 \\
\hline Pu35-28 & 0.07832 & 0.04231 & 0.05071 & 0.02617 & 0.01766 & 0.01529 & 0.05613 & 0.01812 & 0.01019 & 0.01802 & 0.01208 & 0.00500 & 0.00000 & 0.00000 & 0.00000 & 0.00000 & 0.00000 \\
\hline Pu35-29 & 0.05465 & 0.01273 & 0.03866 & 0.05883 & 0.04686 & 0.02967 & 0.03187 & 0.01359 & 0.01251 & 0.03000 & 0.00563 & 0.01500 & 0.00000 & 0.00000 & 0.00000 & 0.00000 & 0.00000 \\
\hline
\end{tabular}

Table 2-6. An Inner-Layer of Test Points with Identifiers and with S, C, Pb, Se, and Cs Set to 0.0005 as Mass Fractions

\begin{tabular}{|c|c|c|c|c|c|c|c|c|c|c|c|c|c|c|c|c|c|}
\hline Test IDs & $\mathrm{Cl}$ & $\mathrm{Ta}$ & $\mathrm{Mg}$ & $\mathrm{K}$ & $\mathrm{Fe}$ & $\mathrm{Na}$ & $\mathrm{F}$ & $\mathrm{Ca}$ & $\mathrm{Ga}$ & $\mathrm{Ni}$ & $\mathrm{Cr}$ & $\mathrm{Cu}$ & $\mathrm{S}$ & $\mathrm{C}$ & $\mathrm{Pb}$ & Se & Cs \\
\hline Pu35-30 & 0.14200 & 0.01000 & 0.01000 & 0.01000 & 0.06000 & 0.01950 & 0.01000 & 0.01000 & 0.01000 & 0.01000 & 0.02850 & 0.00500 & 0.00500 & 0.00500 & 0.00500 & 0.00500 & 0.00500 \\
\hline Pu35-31 & 0.07294 & 0.02429 & 0.02604 & 0.08250 & 0.01006 & 0.01000 & 0.01721 & 0.03600 & 0.01237 & 0.01000 & 0.00858 & 0.01500 & 0.00500 & 0.00500 & 0.00500 & 0.00500 & 0.00500 \\
\hline Pu35-32 & 0.05000 & 0.01000 & 0.12536 & 0.01000 & 0.04964 & 0.01000 & 0.01000 & 0.01000 & 0.01000 & 0.03000 & 0.00500 & 0.00500 & 0.00500 & 0.00500 & 0.00500 & 0.00500 & 0.00500 \\
\hline Pu35-33 & 0.05737 & 0.07732 & 0.02776 & 0.01000 & 0.02157 & 0.01000 & 0.01172 & 0.03600 & 0.01537 & 0.02240 & 0.02048 & 0.01500 & 0.00500 & 0.00500 & 0.00500 & 0.00500 & 0.00500 \\
\hline Pu35-34 & 0.07229 & 0.02560 & 0.04638 & 0.01879 & 0.01000 & 0.04207 & 0.01000 & 0.02699 & 0.02856 & 0.01777 & 0.02155 & 0.00500 & 0.00500 & 0.00500 & 0.00500 & 0.00500 & 0.00500 \\
\hline Pu35-35 & 0.08313 & 0.03890 & 0.04103 & 0.01400 & 0.01409 & 0.01237 & 0.03103 & 0.01619 & 0.02597 & 0.01936 & 0.01393 & 0.01500 & 0.00500 & 0.00500 & 0.00500 & 0.00500 & 0.00500 \\
\hline Pu35-36 & 0.06077 & 0.10491 & 0.03385 & 0.03631 & 0.01158 & 0.01268 & 0.01233 & 0.01083 & 0.01060 & 0.02040 & 0.00574 & 0.00500 & 0.00500 & 0.00500 & 0.00500 & 0.00500 & 0.00500 \\
\hline Pu35-37 & 0.07672 & 0.01212 & 0.02756 & 0.02872 & 0.02410 & 0.01793 & 0.04373 & 0.01980 & 0.02494 & 0.02576 & 0.01862 & 0.00500 & 0.00500 & 0.00500 & 0.00500 & 0.00500 & 0.00500 \\
\hline Pu35-38 & 0.06643 & 0.02176 & 0.03698 & 0.01611 & 0.01485 & 0.06484 & 0.02910 & 0.02524 & 0.02969 & 0.01000 & 0.00500 & 0.00500 & 0.00500 & 0.00500 & 0.00500 & 0.00500 & 0.00500 \\
\hline Pu35-39 & 0.06115 & 0.04978 & 0.01293 & 0.04482 & 0.01218 & 0.05420 & 0.01814 & 0.01104 & 0.01240 & 0.02704 & 0.00632 & 0.01500 & 0.00500 & 0.00500 & 0.00500 & 0.00500 & 0.00500 \\
\hline Pu35-40 & 0.05000 & 0.01000 & 0.07555 & 0.01000 & 0.01000 & 0.01000 & 0.08901 & 0.01000 & 0.01000 & 0.01000 & 0.02850 & 0.01193 & 0.00500 & 0.00500 & 0.00500 & 0.00500 & 0.00500 \\
\hline Pu35-41 & 0.05331 & 0.02651 & 0.04343 & 0.03586 & 0.02332 & 0.04240 & 0.01690 & 0.03035 & 0.02073 & 0.01626 & 0.01092 & 0.00500 & 0.00500 & 0.00500 & 0.00500 & 0.00500 & 0.00500 \\
\hline
\end{tabular}


One additional inner layer of design points was generated using the intervals of Table 2-7. For this case $\mathrm{S}, \mathrm{C}, \mathrm{Pb}$, Se, and Cs were set to 0.005 on a mass fraction basis (based on the minimum practical batch quantity) and 12 additional points were optimally generated for the other elements following the approach outlined above and using JMP. The results are presented in Table 2-8.

Table 2-7. Impurities and Their Possible Concentrations as Mass Fractions in the Feed for the Innermost Layer of Test Points

\begin{tabular}{||c|c|c||}
\hline \hline & \multicolumn{2}{|c|}{$\begin{array}{c}\text { Mass Fraction } \\
\text { Interval }\end{array}$} \\
\hline Element & $\begin{array}{c}\text { Lower } \\
\text { Limit }\end{array}$ & $\begin{array}{c}\text { Upper } \\
\text { Limit }\end{array}$ \\
\hline $\mathrm{Cl}$ & 0.05 & 0.1 \\
\hline $\mathrm{Ta}$ & 0.01 & 0.1 \\
\hline $\mathrm{Mg}$ & 0.01 & 0.1 \\
\hline $\mathrm{K}$ & 0.02 & 0.05 \\
\hline $\mathrm{Fe}$ & 0.02 & 0.04 \\
\hline $\mathrm{Na}$ & 0.02 & 0.05 \\
\hline $\mathrm{F}$ & 0.02 & 0.085 \\
\hline $\mathrm{Ca}$ & 0.02 & 0.03 \\
\hline $\mathrm{Ga}$ & 0.02 & 0.04 \\
\hline $\mathrm{Ni}$ & 0.015 & 0.02 \\
\hline $\mathrm{Cr}$ & 0.01 & 0.02 \\
\hline $\mathrm{Cu}$ & 0.005 & 0.01 \\
\hline
\end{tabular}

Two additional points were generated for the test matrix by computing the centroids of the design points that had been generated so far. These were generated by grouping all of the previous design points by their levels of S, C, Pb, Se, and Cs. Specifically, the average of the design points with $\mathrm{S}, \mathrm{C}, \mathrm{Pb}$, Se, and $\mathrm{Cs}$ all at zero was determined and the average of the design points with $\mathrm{S}$, $\mathrm{C}, \mathrm{Pb}, \mathrm{Se}$, and $\mathrm{Cs}$ all at 0.005 on a mass fraction. These two additional points are provided in Table 2-9.

Finally, 5 additional test points were selected to provide some coverage of the impurity space at a much lower total concentration. The targeted value for all of the impurities in the feed was selected to be 0.04 on a mass fraction basis. This value was chosen, again using the data provided by Moore and Allender as a basis, ${ }^{7}$ to represent the concentration of impurities in the majority of the Pu feeds. The test points were not optimality selected; they were selected subjectively, but with the charge balance constraints imposed. These additional test points are provided in Table 2-10. 
Table 2-8. Inner-Most Layer of Test Points Optimally Selected with Identifiers and with S, C, Pb, Se, and Cs Set to $\mathbf{0 . 0 0 5}$ as Mass Fractions

\begin{tabular}{|c|c|c|c|c|c|c|c|c|c|c|c|c|c|c|c|c|c|}
\hline Test IDs & $\mathrm{Cl}$ & $\mathrm{Ta}$ & $\mathrm{Mg}$ & $\mathrm{K}$ & $\mathrm{Fe}$ & $\mathrm{Na}$ & $\mathrm{F}$ & $\mathrm{Ca}$ & $\mathrm{Ga}$ & $\mathrm{Ni}$ & $\mathrm{Cr}$ & $\mathrm{Cu}$ & $\mathrm{S}$ & $\mathrm{C}$ & $\mathrm{Pb}$ & Se & Cs \\
\hline Pu35-42 & 0.05539 & 0.01190 & 0.01554 & 0.04813 & 0.03716 & 0.02417 & 0.03803 & 0.02516 & 0.03587 & 0.01777 & 0.01088 & 0.00500 & 0.00500 & 0.00500 & 0.00500 & 0.00500 & 0.00500 \\
\hline Pu35-43 & 0.05169 & 0.01533 & 0.05178 & 0.02684 & 0.02155 & 0.02487 & 0.04862 & 0.02796 & 0.02107 & 0.01868 & 0.01161 & 0.00500 & 0.00500 & 0.00500 & 0.00500 & 0.00500 & 0.00500 \\
\hline Pu35-44 & 0.05000 & 0.10000 & 0.01000 & 0.02000 & 0.02000 & 0.02000 & 0.02000 & 0.02000 & 0.02000 & 0.02000 & 0.02000 & 0.00500 & 0.00500 & 0.00500 & 0.00500 & 0.00500 & 0.00500 \\
\hline Pu35-45 & 0.05968 & 0.01515 & 0.04505 & 0.02723 & 0.02872 & 0.02463 & 0.03183 & 0.02337 & 0.03145 & 0.01514 & 0.01275 & 0.01000 & 0.00500 & 0.00500 & 0.00500 & 0.00500 & 0.00500 \\
\hline Pu35-46 & 0.05608 & 0.01001 & 0.01560 & 0.03233 & 0.02917 & 0.03403 & 0.05880 & 0.02309 & 0.02060 & 0.01529 & 0.02000 & 0.01000 & 0.00500 & 0.00500 & 0.00500 & 0.00500 & 0.00500 \\
\hline Pu35-47 & 0.06386 & 0.01639 & 0.04352 & 0.03211 & 0.02928 & 0.04080 & 0.02000 & 0.02904 & 0.02000 & 0.01500 & 0.01000 & 0.00500 & 0.00500 & 0.00500 & 0.00500 & 0.00500 & 0.00500 \\
\hline Pu35-48 & 0.06884 & 0.01000 & 0.04850 & 0.03241 & 0.02161 & 0.02098 & 0.03884 & 0.02126 & 0.02041 & 0.02000 & 0.01214 & 0.01000 & 0.00500 & 0.00500 & 0.00500 & 0.00500 & 0.00500 \\
\hline Pu35-49 & 0.08085 & 0.03114 & 0.02244 & 0.02795 & 0.02117 & 0.02705 & 0.04248 & 0.02193 & 0.02000 & 0.01500 & 0.01000 & 0.00500 & 0.00500 & 0.00500 & 0.00500 & 0.00500 & 0.00500 \\
\hline Pu35-50 & 0.10000 & 0.01000 & 0.01005 & 0.02255 & 0.04000 & 0.02000 & 0.02000 & 0.03000 & 0.02240 & 0.02000 & 0.02000 & 0.01000 & 0.00500 & 0.00500 & 0.00500 & 0.00500 & 0.00500 \\
\hline Pu35-51 & 0.05000 & 0.01000 & 0.01000 & 0.02000 & 0.04000 & 0.05000 & 0.05671 & 0.02000 & 0.03526 & 0.01803 & 0.01000 & 0.00500 & 0.00500 & 0.00500 & 0.00500 & 0.00500 & 0.00500 \\
\hline Pu35-52 & 0.08329 & 0.01421 & 0.02709 & 0.03289 & 0.02114 & 0.03234 & 0.02062 & 0.02096 & 0.03417 & 0.01566 & 0.01764 & 0.00500 & 0.00500 & 0.00500 & 0.00500 & 0.00500 & 0.00500 \\
\hline Pu35-53 & 0.06286 & 0.01034 & 0.01637 & 0.04332 & 0.02000 & 0.03756 & 0.03324 & 0.03000 & 0.03363 & 0.01624 & 0.01145 & 0.01000 & 0.00500 & 0.00500 & 0.00500 & 0.00500 & 0.00500 \\
\hline
\end{tabular}

Table 2-9. Two Centroids with Identifiers Determined from the Other Design Points of the Test Matrix

\begin{tabular}{|c|c|c|c|c|c|c|c|c|c|c|c|c|c|c|c|c|c|}
\hline Test IDs & $\mathrm{Cl}$ & $\mathrm{Ta}$ & $\mathrm{Mg}$ & $\mathrm{K}$ & $\mathrm{Fe}$ & $\mathrm{Na}$ & $\mathrm{F}$ & $\mathrm{Ca}$ & $\mathrm{Ga}$ & $\mathrm{Ni}$ & $\mathrm{Cr}$ & $\mathrm{Cu}$ & $\mathrm{S}$ & $\mathrm{C}$ & $\mathrm{Pb}$ & Se & Cs \\
\hline Pu35-54 & 0.06817 & 0.02980 & 0.04164 & 0.03638 & 0.02612 & 0.03144 & 0.03485 & 0.02045 & 0.02219 & 0.01608 & 0.01373 & 0.00917 & 0.00000 & 0.00000 & 0.00000 & 0.00000 & 0.00000 \\
\hline Pu35-55 & 0.06916 & 0.02683 & 0.03435 & 0.02820 & 0.02539 & 0.02701 & 0.02933 & 0.02285 & 0.02184 & 0.01723 & 0.01448 & 0.00832 & 0.00500 & 0.00500 & 0.00500 & 0.00500 & 0.00500 \\
\hline
\end{tabular}

Table 2-10. Five Test Points with Identifiers Selected to Cover a 0.04 Level (in mass fractions) of Total Impurity in the Feed

\begin{tabular}{|c|c|c|c|c|c|c|c|c|c|c|c|c|c|c|c|c|c|}
\hline Test IDs & $\mathrm{Cl}$ & $\mathrm{Ta}$ & $\mathrm{Mg}$ & $\mathrm{K}$ & $\mathrm{Fe}$ & $\mathrm{Na}$ & $\mathrm{F}$ & $\mathrm{Ca}$ & $\mathrm{Ga}$ & $\mathrm{Ni}$ & $\mathrm{Cr}$ & $\mathrm{Cu}$ & $\mathrm{S}$ & $\mathrm{C}$ & $\mathrm{Pb}$ & $\mathrm{Se}$ & Cs \\
\hline Pu04-01 & 0.025 & 0 & 0.015 & 0 & 0 & 0 & 0 & 0 & 0 & 0 & 0 & 0 & 0 & 0 & 0 & 0 & 0 \\
\hline Pu04-02 & 0 & 0 & 0.005 & 0.005 & 0.005 & 0.005 & 0.015 & 0 & 0 & 0 & 0 & 0 & 0 & 0 & 0 & 0 & 0.005 \\
\hline Pu04-03 & 0.005000 & 0 & 0.005 & 0 & 0.005000 & 0 & 0.005000 & 0 & 0 & 0 & 0.000000 & 0.005000 & 0.000000 & 0.000000 & 0.005000 & 0.005000 & 0.005000 \\
\hline Pu04-04 & 0 & 0 & 0.005000 & 0.005000 & 0.005000 & 0.005000 & 0 & 0.005000 & 0 & 0.005000 & 0.005000 & 0.005000 & 0 & 0 & 0 & 0 & 0 \\
\hline Pu04-05 & 0.01 & 0 & 0 & 0 & 0 & 0.02 & 0.01 & 0 & 0 & 0 & 0 & 0 & 0 & 0 & 0 & 0 & 0 \\
\hline
\end{tabular}


Thus, the impurity compositions of Tables 2-3, 2-5, 2-6, 2-8, 2-9, and 2-10 provide the 60 test conditions that will make up this impurity solubility study. Table A1 in the Appendix provides the linear correlations of these design points. While there were some substantial correlations among certain pairs of the impurities (e.g., $\mathrm{S}$ and $\mathrm{Cs}$ at 0.767 and $\mathrm{Pb}$ and Se at 0.7497), these are considered to be artifacts of the restrictions placed on the impurity space that were described above and should not adversely impact the outcome of the study.

Exhibit A1 in the Appendix provides a scatter plot matrix of the test points showing the coverage (two elements at a time) of the impurity space by the test matrix determined for this study. Exhibit A2 in the Appendix provides a closer look at the coverage for each of the elements considered. 
WSRC-STI-2007-00386

Revision 0

This page intentionally left blank. 


\subsection{Surrogate Glass Compositions}

The 60 sets of impurity concentrations described in the previous section were combined with $\mathrm{HfO}_{2}$ as a surrogate for $\mathrm{PuO}_{2}$ to form the feed material. The feed was then combined with LaBS Frit $\mathrm{X}^{11}$ at a mass ratio of $14 \%$ feed to $86 \%$ frit. A $14 \%$ feed value represents a nominal upper bound for "waste loading" projected for Pu vitrification operations. ${ }^{12}$ The composition of LaBS Frit $\mathrm{X}$ is given in Table 3-1. The 60 glass compositions, given as oxides (except for the anions $\mathrm{Cl}^{-}$and $\mathrm{F}^{-}$), which result from combining the surrogate Pu/impurity feeds with Frit $\mathrm{X}$ are listed in Table 3-2.

Table 3-1. Composition of LaBS Frit X (in wt\% oxides).

\begin{tabular}{||c|c|}
\hline \hline Component & wt\% \\
\hline $\mathrm{Al}_{2} \mathrm{O}_{3}$ & 10.00 \\
\hline $\mathrm{B}_{2} \mathrm{O}_{3}$ & 13.00 \\
\hline $\mathrm{Gd}_{2} \mathrm{O}_{3}$ & 13.50 \\
\hline $\mathrm{HfO}_{2}$ & 7.00 \\
\hline $\mathrm{La}_{2} \mathrm{O}_{3}$ & 19.00 \\
\hline $\mathrm{Nd}_{2} \mathrm{O}_{3}$ & 15.00 \\
\hline $\mathrm{SiO}_{2}$ & 20.00 \\
\hline $\mathrm{SrO}$ & 2.50 \\
\hline
\end{tabular}


Table 3-2. Target Compositions for the 60 Surrogate Glasses (in wt\%).

\begin{tabular}{|c|c|c|c|c|c|c|c|c|c|c|c|c|c|}
\hline Glass ID & בCl & $\mathbf{T a}_{2} \mathbf{O}_{5}$ & MgO & $\mathrm{K}_{2} \mathrm{O}$ & $\mathrm{Fe}_{2} \mathbf{O}_{3}$ & $\mathrm{Na}_{2} \mathrm{O}$ & $\mathbf{F}$ & בaO & $\mathbf{G a}_{2} \mathbf{O}_{3}$ & $\mathrm{NiO}$ & $\mathrm{Cr}_{2} \mathrm{O}_{3}$ & $\begin{array}{l}\mathrm{CuO} \\
\end{array}$ & $\mathrm{SO}_{4}{ }^{2-}$ \\
\hline Pu35-01 & 0.58 & 0.07 & 1.62 & 0.26 & 0.39 & 0.80 & 0.00 & 0.00 & 0.95 & 0.21 & 0.00 & 0.15 & 0.00 \\
\hline Pu35-02 & 0.58 & 0.07 & 1.45 & 0.74 & 0.08 & 0.35 & 0.45 & 0.36 & 0.08 & 0.15 & 0.33 & 0.07 & 0.17 \\
\hline Pu35-03 & 0.57 & 0.18 & 0.54 & 0.31 & 0.14 & 1.48 & 0.00 & 0.77 & 0.45 & 0.07 & 0.64 & 0.00 & 0.00 \\
\hline Pu35-04 & 0.59 & 0.46 & 1.06 & 0.45 & 0.27 & 0.56 & 0.52 & 0.32 & 0.36 & 0.07 & 0.09 & 0.07 & 0.00 \\
\hline Pu35-05 & 0.58 & 0.09 & 0.52 & 0.78 & 1.32 & 0.35 & 0.00 & 0.13 & 0.29 & 0.00 & 0.64 & 0.29 & 0.00 \\
\hline Pu35-06 & 0.60 & 0.10 & 0.91 & 0.27 & 0.97 & 0.80 & 0.48 & 0.29 & 0.00 & 0.28 & 0.22 & 0.00 & 0.17 \\
\hline Pu35-07 & 0.62 & 1.30 & 0.54 & 0.42 & 0.09 & 0.61 & 0.19 & 0.20 & 0.08 & 0.37 & 0.13 & 0.16 & 0.17 \\
\hline Pu35-08 & 0.62 & 0.39 & 0.88 & 0.77 & 0.89 & 0.40 & 0.30 & 0.24 & 0.16 & 0.25 & 0.09 & 0.07 & 0.00 \\
\hline Pu35-09 & 0.64 & 0.11 & 0.53 & 1.54 & 0.00 & 1.13 & 0.00 & 0.10 & 0.13 & 0.19 & 0.08 & 0.25 & 0.17 \\
\hline Pu35-10 & 0.65 & 0.27 & 0.81 & 0.36 & 0.59 & 0.67 & 0.38 & 0.08 & 0.71 & 0.07 & 0.08 & 0.07 & 0.17 \\
\hline Pu35-11 & 0.69 & 0.69 & 0.99 & 0.38 & 0.08 & 0.69 & 0.06 & 0.40 & 0.21 & 0.17 & 0.40 & 0.00 & 0.17 \\
\hline Pu35-12 & 0.65 & 0.59 & 0.66 & 0.28 & 0.19 & 0.79 & 0.33 & 0.08 & 0.36 & 0.47 & 0.40 & 0.18 & 0.00 \\
\hline Pu35-13 & 0.77 & 0.84 & 0.76 & 0.44 & 0.37 & 1.09 & 0.06 & 0.00 & 0.08 & 0.00 & 0.37 & 0.15 & 0.00 \\
\hline Pu35-14 & 0.80 & 0.34 & 0.44 & 0.20 & 1.00 & 1.07 & 0.08 & 0.38 & 0.27 & 0.07 & 0.13 & 0.07 & 0.00 \\
\hline Pu35-15 & 1.00 & 0.00 & 0.54 & 0.59 & 0.00 & 0.88 & 0.00 & 0.00 & 1.27 & 0.60 & 0.00 & 0.00 & 0.00 \\
\hline Pu35-16 & 0.95 & 0.29 & 0.73 & 0.00 & 0.46 & 1.23 & 0.00 & 0.70 & 0.15 & 0.13 & 0.00 & 0.29 & 0.17 \\
\hline Pu35-17 & 1.11 & 0.55 & 0.40 & 0.43 & 0.00 & 1.04 & 0.06 & 0.08 & 0.68 & 0.07 & 0.31 & 0.10 & 0.17 \\
\hline Pu35-18 & 0.58 & 0.07 & 1.04 & 1.10 & 0.08 & 0.94 & 0.06 & 0.57 & 0.08 & 0.07 & 0.48 & 0.07 & 0.00 \\
\hline Pu35-19 & 0.58 & 0.07 & 1.38 & 0.37 & 0.78 & 0.78 & 0.38 & 0.08 & 0.08 & 0.07 & 0.48 & 0.07 & 0.00 \\
\hline Pu35-20 & 0.58 & 0.51 & 0.55 & 0.85 & 0.28 & 0.50 & 0.29 & 0.23 & 0.51 & 0.29 & 0.40 & 0.07 & 0.00 \\
\hline Pu35-21 & 0.58 & 1.14 & 1.28 & 0.41 & 0.08 & 0.59 & 0.06 & 0.08 & 0.62 & 0.07 & 0.09 & 0.07 & 0.00 \\
\hline Pu35-22 & 0.60 & 0.52 & 0.69 & 0.55 & 0.37 & 0.74 & 0.47 & 0.59 & 0.08 & 0.08 & 0.15 & 0.22 & 0.00 \\
\hline Pu35-23 & 0.59 & 0.83 & 0.67 & 0.16 & 0.56 & 0.93 & 0.09 & 0.16 & 0.53 & 0.12 & 0.29 & 0.22 & 0.00 \\
\hline Pu35-24 & 0.63 & 0.15 & 0.67 & 0.53 & 0.41 & 0.58 & 0.24 & 0.40 & 0.83 & 0.10 & 0.37 & 0.22 & 0.00 \\
\hline Pu35-25 & 0.67 & 0.59 & 0.48 & 0.70 & 0.83 & 0.48 & 0.07 & 0.28 & 0.26 & 0.35 & 0.17 & 0.22 & 0.00 \\
\hline Pu35-26 & 0.66 & 0.22 & 0.89 & 0.25 & 0.47 & 0.77 & 0.10 & 0.43 & 0.79 & 0.22 & 0.27 & 0.07 & 0.00 \\
\hline Pu35-27 & 0.72 & 0.67 & 0.61 & 0.52 & 0.46 & 0.65 & 0.24 & 0.32 & 0.27 & 0.07 & 0.48 & 0.07 & 0.00 \\
\hline Pu35-28 & 0.72 & 0.54 & 0.93 & 0.39 & 0.08 & 0.74 & 0.10 & 0.11 & 0.41 & 0.36 & 0.48 & 0.22 & 0.00 \\
\hline Pu35-29 & 0.84 & 0.34 & 0.47 & 0.84 & 0.18 & 0.95 & 0.36 & 0.08 & 0.70 & 0.07 & 0.09 & 0.07 & 0.00 \\
\hline Pu35-30 & 0.58 & 0.07 & 0.46 & 1.11 & 0.08 & 0.90 & 0.06 & 0.46 & 0.75 & 0.07 & 0.08 & 0.07 & 0.17 \\
\hline Pu35-31 & 0.58 & 0.07 & 0.60 & 1.12 & 0.83 & 0.47 & 0.47 & 0.08 & 0.08 & 0.17 & 0.09 & 0.07 & 0.17 \\
\hline Pu35-32 & 0.58 & 0.07 & 1.39 & 0.26 & 0.08 & 0.69 & 0.40 & 0.08 & 0.90 & 0.07 & 0.08 & 0.07 & 0.17 \\
\hline Pu35-33 & 0.57 & 0.07 & 1.37 & 0.08 & 0.56 & 0.90 & 0.13 & 0.44 & 0.08 & 0.07 & 0.48 & 0.07 & 0.17 \\
\hline Pu35-34 & 0.58 & 0.71 & 1.38 & 0.58 & 0.08 & 0.48 & 0.06 & 0.37 & 0.08 & 0.07 & 0.08 & 0.22 & 0.17 \\
\hline Pu35-35 & 0.58 & 1.12 & 0.46 & 0.07 & 0.82 & 0.93 & 0.06 & 0.08 & 0.39 & 0.07 & 0.08 & 0.07 & 0.17 \\
\hline Pu35-36 & 0.60 & 0.51 & 0.89 & 0.43 & 0.11 & 0.67 & 0.16 & 0.08 & 0.31 & 0.33 & 0.37 & 0.22 & 0.17 \\
\hline Pu35-37 & 0.60 & 0.35 & 1.02 & 0.36 & 0.28 & 0.65 & 0.10 & 0.17 & 0.36 & 0.37 & 0.40 & 0.07 & 0.17 \\
\hline Pu35-38 & 0.66 & 0.53 & 0.73 & 0.45 & 0.17 & 0.66 & 0.31 & 0.43 & 0.30 & 0.18 & 0.18 & 0.07 & 0.17 \\
\hline Pu35-39 & 0.69 & 0.50 & 0.70 & 0.77 & 0.29 & 0.70 & 0.18 & 0.08 & 0.31 & 0.07 & 0.31 & 0.07 & 0.17 \\
\hline Pu35-40 & 0.72 & 0.07 & 0.65 & 0.50 & 0.56 & 0.65 & 0.14 & 0.41 & 0.39 & 0.10 & 0.32 & 0.22 & 0.17 \\
\hline Pu35-41 & 0.93 & 0.07 & 1.39 & 0.34 & 0.08 & 0.94 & 0.06 & 0.08 & 0.08 & 0.44 & 0.08 & 0.15 & 0.17 \\
\hline Pu35-42 & 0.58 & 0.21 & 1.08 & 0.84 & 0.17 & 0.78 & 0.12 & 0.16 & 0.16 & 0.15 & 0.34 & 0.14 & 0.17 \\
\hline Pu35-43 & 0.58 & 0.49 & 0.65 & 0.21 & 0.57 & 0.74 & 0.20 & 0.35 & 0.35 & 0.20 & 0.25 & 0.14 & 0.17 \\
\hline Pu35-44 & 0.58 & 0.54 & 0.80 & 0.31 & 0.58 & 0.66 & 0.19 & 0.28 & 0.30 & 0.15 & 0.25 & 0.11 & 0.17 \\
\hline Pu35-45 & 0.58 & 0.70 & 0.75 & 0.20 & 0.46 & 0.73 & 0.12 & 0.23 & 0.48 & 0.22 & 0.17 & 0.11 & 0.17 \\
\hline Pu35-46 & 0.59 & 0.45 & 0.73 & 0.41 & 0.17 & 0.63 & 0.35 & 0.17 & 0.54 & 0.30 & 0.17 & 0.15 & 0.17 \\
\hline Pu35-47 & 0.61 & 0.85 & 0.61 & 0.25 & 0.17 & 0.73 & 0.12 & 0.40 & 0.19 & 0.29 & 0.34 & 0.14 & 0.17 \\
\hline Pu35-48 & 0.63 & 0.35 & 0.79 & 0.29 & 0.50 & 0.73 & 0.20 & 0.37 & 0.34 & 0.19 & 0.23 & 0.11 & 0.17 \\
\hline Pu35-49 & 0.64 & 0.27 & 0.77 & 0.63 & 0.52 & 0.64 & 0.19 & 0.32 & 0.19 & 0.20 & 0.19 & 0.14 & 0.17 \\
\hline Pu35-50 & 0.64 & 0.18 & 0.66 & 0.69 & 0.49 & 0.65 & 0.20 & 0.26 & 0.32 & 0.24 & 0.25 & 0.11 & 0.17 \\
\hline Pu35-51 & 0.65 & 0.32 & 0.90 & 0.26 & 0.56 & 0.75 & 0.22 & 0.16 & 0.16 & 0.29 & 0.32 & 0.11 & 0.17 \\
\hline Pu35-52 & 0.69 & 0.14 & 0.82 & 0.37 & 0.39 & 0.71 & 0.14 & 0.17 & 0.58 & 0.23 & 0.33 & 0.14 & 0.17 \\
\hline Pu35-53 & 0.70 & 0.77 & 0.62 & 0.47 & 0.17 & 0.79 & 0.35 & 0.16 & 0.16 & 0.15 & 0.17 & 0.11 & 0.17 \\
\hline Pu35-54 & 0.64 & 0.46 & 0.81 & 0.57 & 0.42 & 0.70 & 0.21 & 0.28 & 0.41 & 0.16 & 0.30 & 0.13 & 0.00 \\
\hline Pu35-55 & 0.63 & 0.39 & 0.84 & 0.46 & 0.36 & 0.72 & 0.19 & 0.24 & 0.32 & 0.19 & 0.23 & 0.12 & 0.17 \\
\hline Pu04-01 & 0.12 & 0.00 & 0.00 & 0.21 & 0.00 & 0.24 & 0.00 & 0.00 & 0.00 & 0.00 & 0.00 & 0.00 & 0.00 \\
\hline $\mathrm{Pu} 04-02$ & 0.00 & 0.00 & 0.08 & 0.07 & 0.00 & 0.32 & 0.12 & 0.00 & 0.00 & 0.00 & 0.00 & 0.00 & 0.00 \\
\hline $\mathrm{Pu} 04-03$ & 0.06 & 0.00 & 0.16 & 0.00 & 0.17 & 0.16 & 0.06 & 0.00 & 0.00 & 0.00 & 0.00 & 0.00 & 0.00 \\
\hline $\mathrm{Pu} 04-04$ & 0.00 & 0.00 & 0.08 & 0.07 & 0.08 & 0.08 & 0.00 & 0.08 & 0.00 & 0.08 & 0.09 & 0.07 & 0.00 \\
\hline $\mathrm{Pu} 04-05$ & 0.12 & 0.00 & 0.00 & 0.00 & 0.00 & 0.32 & 0.12 & 0.00 & 0.00 & 0.00 & 0.00 & 0.00 & 0.00 \\
\hline
\end{tabular}


Table 3-2. Target Compositions for the 60 Surrogate Glasses (in wt\%). (continued)

\begin{tabular}{|c|c|c|c|c|c|c|c|c|c|c|c|c|c|}
\hline Glass ID & C & $\mathrm{PbO}$ & $\mathrm{SeO}_{2}$ & $\mathrm{Cs}_{2} \mathrm{O}$ & $\mathrm{HfO}_{2}$ & $\mathrm{Al}_{2} \mathrm{O}_{3}$ & $\mathrm{~B}_{2} \mathrm{O}_{3}$ & $\mathbf{G d}_{2} \mathbf{O}_{3}$ & $\mathrm{La}_{2} \mathrm{O}_{3}$ & $\mathrm{Nd}_{2} \mathrm{O}_{3}$ & $\mathrm{SiO}_{2}$ & SrO & Total \\
\hline Pu35-01 & 0.06 & 0.00 & 0.08 & 0.00 & 14.86 & 8.60 & 11.18 & 11.61 & 16.34 & 12.90 & 17.20 & 2.15 & 100 \\
\hline Pu35-02 & 0.00 & 0.06 & 0.08 & 0.06 & 14.92 & 8.60 & 11.18 & 11.61 & 16.34 & 12.90 & 17.20 & 2.15 & 100 \\
\hline Pu35-03 & 0.00 & 0.00 & 0.00 & 0.06 & 14.81 & 8.60 & 11.18 & 11.61 & 16.34 & 12.90 & 17.20 & 2.15 & 100 \\
\hline Pu35-04 & 0.06 & 0.08 & 0.08 & 0.00 & 15.00 & 8.60 & 11.18 & 11.61 & 16.34 & 12.90 & 17.20 & 2.15 & 100 \\
\hline Pu35-05 & 0.06 & 0.07 & 0.00 & 0.06 & 14.85 & 8.60 & 11.18 & 11.61 & 16.34 & 12.90 & 17.20 & 2.15 & 100 \\
\hline Pu35-06 & 0.06 & 0.00 & 0.00 & 0.00 & 14.87 & 8.60 & 11.18 & 11.61 & 16.34 & 12.90 & 17.20 & 2.15 & 100 \\
\hline Pu35-07 & 0.06 & 0.06 & 0.00 & 0.06 & 14.96 & 8.60 & 11.18 & 11.61 & 16.34 & 12.90 & 17.20 & 2.15 & 100 \\
\hline Pu35-08 & 0.00 & 0.00 & 0.00 & 0.00 & 14.95 & 8.60 & 11.18 & 11.61 & 16.34 & 12.90 & 17.20 & 2.15 & 100 \\
\hline Pu35-09 & 0.06 & 0.08 & 0.08 & 0.00 & 14.92 & 8.60 & 11.18 & 11.61 & 16.34 & 12.90 & 17.20 & 2.15 & 100 \\
\hline Pu35-10 & 0.00 & 0.06 & 0.08 & 0.06 & 14.90 & 8.60 & 11.18 & 11.61 & 16.34 & 12.90 & 17.20 & 2.15 & 100 \\
\hline Pu35-11 & 0.06 & 0.07 & 0.08 & 0.00 & 14.87 & 8.60 & 11.18 & 11.61 & 16.34 & 12.90 & 17.20 & 2.15 & 100 \\
\hline Pu35-12 & 0.00 & 0.00 & 0.08 & 0.00 & 14.96 & 8.60 & 11.18 & 11.61 & 16.34 & 12.90 & 17.20 & 2.15 & 100 \\
\hline Pu35-13 & 0.00 & 0.08 & 0.00 & 0.06 & 14.96 & 8.60 & 11.18 & 11.61 & 16.34 & 12.90 & 17.20 & 2.15 & 100 \\
\hline Pu35-14 & 0.06 & 0.06 & 0.08 & 0.06 & 14.90 & 8.60 & 11.18 & 11.61 & 16.34 & 12.90 & 17.20 & 2.15 & 100 \\
\hline Pu35-15 & 0.00 & 0.08 & 0.00 & 0.06 & 15.00 & 8.60 & 11.18 & 11.61 & 16.34 & 12.90 & 17.20 & 2.15 & 100 \\
\hline Pu35-16 & 0.00 & 0.06 & 0.00 & 0.00 & 14.85 & 8.60 & 11.18 & 11.61 & 16.34 & 12.90 & 17.20 & 2.15 & 100 \\
\hline Pu35-17 & 0.06 & 0.00 & 0.00 & 0.00 & 14.95 & 8.60 & 11.18 & 11.61 & 16.34 & 12.90 & 17.20 & 2.15 & 100 \\
\hline Pu35-18 & 0.00 & 0.00 & 0.00 & 0.00 & 14.88 & 8.60 & 11.18 & 11.61 & 16.34 & 12.90 & 17.20 & 2.15 & 100 \\
\hline Pu35-19 & 0.00 & 0.00 & 0.00 & 0.00 & 14.89 & 8.60 & 11.18 & 11.61 & 16.34 & 12.90 & 17.20 & 2.15 & 100 \\
\hline Pu35-20 & 0.00 & 0.00 & 0.00 & 0.00 & 14.95 & 8.60 & 11.18 & 11.61 & 16.34 & 12.90 & 17.20 & 2.15 & 100 \\
\hline Pu35-21 & 0.00 & 0.00 & 0.00 & 0.00 & 14.94 & 8.60 & 11.18 & 11.61 & 16.34 & 12.90 & 17.20 & 2.15 & 100 \\
\hline Pu35-22 & 0.00 & 0.00 & 0.00 & 0.00 & 14.98 & 8.60 & 11.18 & 11.61 & 16.34 & 12.90 & 17.20 & 2.15 & 00 \\
\hline Pu35-23 & 0.00 & 0.00 & 0.00 & 0.00 & 14.88 & 8.60 & 11.18 & 11.61 & 16.34 & 12.90 & 17.20 & 2.15 & 100 \\
\hline Pu35-24 & 0.00 & 0.00 & 0.00 & 0.00 & 14.90 & 8.60 & 11.18 & 11.61 & 16.34 & 12.90 & 17.20 & 2.15 & 100 \\
\hline Pu35-25 & 0.00 & 0.00 & 0.00 & 0.00 & 14.92 & 8.60 & 11.18 & 11.61 & 16.34 & 12.90 & 17.20 & 2.15 & 100 \\
\hline Pu35-26 & 0.00 & 0.00 & 0.00 & 0.00 & 14.87 & 8.60 & 11.18 & 11.61 & 16.34 & 12.90 & 17.20 & 2.15 & 100 \\
\hline Pu35-27 & 0.00 & 0.00 & 0.00 & 0.00 & 14.94 & 8.60 & 11.18 & 11.61 & 16.34 & 12.90 & 17.20 & 2.15 & 100 \\
\hline Pu35-28 & 0.00 & 0.00 & 0.00 & 0.00 & 14.93 & 8.60 & 11.18 & 11.61 & 16.34 & 12.90 & 17.20 & 2.15 & 100 \\
\hline Pu35-29 & 0.00 & 0.00 & 0.00 & 0.00 & 15.03 & 8.60 & 11.18 & 11.61 & 16.34 & 12.90 & 17.20 & 2.15 & 100 \\
\hline Pu35-30 & 0.06 & 0.06 & 0.08 & 0.06 & 14.88 & 8.60 & 11.18 & 11.61 & 16.34 & 12.90 & 17.20 & 2.15 & 100 \\
\hline Pu35-31 & 0.06 & 0.06 & 0.08 & 0.06 & 14.95 & 8.60 & 11.18 & 11.61 & 16.34 & 12.90 & 17.20 & 2.15 & 100 \\
\hline Pu35-32 & 0.06 & 0.06 & 0.08 & 0.06 & 14.90 & 8.60 & 11.18 & 11.61 & 16.34 & 12.90 & 17.20 & 2.15 & 100 \\
\hline Pu35-33 & 0.06 & 0.06 & 0.08 & 0.06 & 14.78 & 8.60 & 11.18 & 11.61 & 16.34 & 12.90 & 17.20 & 2.15 & 100 \\
\hline Pu35-34 & 0.06 & 0.06 & 0.08 & 0.06 & 14.89 & 8.60 & 11.18 & 11.61 & 16.34 & 12.90 & 17.20 & 2.15 & 100 \\
\hline Pu35-35 & 0.06 & 0.06 & 0.08 & 0.06 & 14.85 & 8.60 & 11.18 & 11.61 & 16.34 & 12.90 & 17.20 & 2.15 & 100 \\
\hline Pu35-36 & 0.06 & 0.06 & 0.08 & 0.06 & 14.89 & 8.60 & 11.18 & 11.61 & 16.34 & 12.90 & 17.20 & 2.15 & 100 \\
\hline Pu35-37 & 0.06 & 0.06 & 0.08 & 0.06 & 14.85 & 8.60 & 11.18 & 11.61 & 16.34 & 12.90 & 17.20 & 2.15 & 100 \\
\hline Pu35-38 & 0.06 & 0.06 & 0.08 & 0.06 & 14.93 & 8.60 & 11.18 & 11.61 & 16.34 & 12.90 & 17.20 & 2.15 & 100 \\
\hline Pu35-39 & 0.06 & 0.06 & 0.08 & 0.06 & 14.92 & 8.60 & 11.18 & 11.61 & 16.34 & 12.90 & 17.20 & 2.15 & 100 \\
\hline Pu35-40 & 0.06 & 0.06 & 0.08 & 0.06 & 14.86 & 8.60 & 11.18 & 11.61 & 16.34 & 12.90 & 17.20 & 2.15 & 100 \\
\hline Pu35-41 & 0.06 & 0.06 & 0.08 & 0.06 & 14.93 & 8.60 & 11.18 & 11.61 & 16.34 & 12.90 & 17.20 & 2.15 & 100 \\
\hline Pu35-42 & 0.06 & 0.06 & 0.08 & 0.06 & 14.88 & 8.60 & 11.18 & 11.61 & 16.34 & 12.90 & 17.20 & 2.15 & 100 \\
\hline Pu35-43 & 0.06 & 0.06 & 0.08 & 0.06 & 14.85 & 8.60 & 11.18 & 11.61 & 16.34 & 12.90 & 17.20 & 2.15 & 100 \\
\hline Pu35-44 & 0.06 & 0.06 & 0.08 & 0.06 & 14.86 & 8.60 & 11.18 & 11.61 & 16.34 & 12.90 & 17.20 & 2.15 & 100 \\
\hline Pu35-45 & 0.06 & 0.06 & 0.08 & 0.06 & 14.86 & 8.60 & 11.18 & 11.61 & 16.34 & 12.90 & 17.20 & 2.15 & 100 \\
\hline Pu35-46 & 0.06 & 0.06 & 0.08 & 0.06 & 14.92 & 8.60 & 11.18 & 11.61 & 16.34 & 12.90 & 17.20 & 2.15 & 100 \\
\hline Pu35-47 & 0.06 & 0.06 & 0.08 & 0.06 & 14.88 & 8.60 & 11.18 & 11.61 & 16.34 & 12.90 & 17.20 & 2.15 & 100 \\
\hline Pu35-48 & 0.06 & 0.06 & 0.08 & 0.06 & 14.86 & 8.60 & 11.18 & 11.61 & 16.34 & 12.90 & 17.20 & 2.15 & 100 \\
\hline Pu35-49 & 0.06 & 0.06 & 0.08 & 0.06 & 14.89 & 8.60 & 11.18 & 11.61 & 16.34 & 12.90 & 17.20 & 2.15 & 100 \\
\hline Pu35-50 & 0.06 & 0.06 & 0.08 & 0.06 & 14.89 & 8.60 & 11.18 & 11.61 & 16.34 & 12.90 & 17.20 & 2.15 & 100 \\
\hline Pu35-51 & 0.06 & 0.06 & 0.08 & 0.06 & 14.87 & 8.60 & 11.18 & 11.61 & 16.34 & 12.90 & 17.20 & 2.15 & 100 \\
\hline Pu35-52 & 0.06 & 0.06 & 0.08 & 0.06 & 14.86 & 8.60 & 11.18 & 11.61 & 16.34 & 12.90 & 17.20 & 2.15 & 100 \\
\hline Pu35-53 & 0.06 & 0.06 & 0.08 & 0.06 & 14.97 & 8.60 & 11.18 & 11.61 & 16.34 & 12.90 & 17.20 & 2.15 & 100 \\
\hline Pu35-54 & 0.00 & 0.00 & 0.00 & 0.00 & 14.93 & 8.60 & 11.18 & 11.61 & 16.34 & 12.90 & 17.20 & 2.15 & 100 \\
\hline Pu35-55 & 0.06 & 0.06 & 0.08 & 0.06 & 14.88 & 8.60 & 11.18 & 11.61 & 16.34 & 12.90 & 17.20 & 2.15 & 100 \\
\hline Pu04-01 & 0.00 & 0.00 & 0.00 & 0.00 & 19.45 & 8.60 & 11.18 & 11.61 & 16.34 & 12.90 & 17.20 & 2.15 & 100 \\
\hline Pu04-02 & 0.00 & 0.00 & 0.00 & 0.00 & 19.43 & 8.60 & 11.18 & 11.61 & 16.34 & 12.90 & 17.20 & 2.15 & 100 \\
\hline Pu04-03 & 0.00 & 0.00 & 0.00 & 0.00 & 19.42 & 8.60 & 11.18 & 11.61 & 16.34 & 12.90 & 17.20 & 2.15 & 100 \\
\hline Pu04-04 & 0.00 & 0.00 & 0.00 & 0.00 & 19.39 & 8.60 & 11.18 & 11.61 & 16.34 & 12.90 & 17.20 & 2.15 & 100 \\
\hline Pu04-05 & 0.00 & 0.00 & 0.00 & 0.00 & 19.46 & 8.60 & 11.18 & 11.61 & 16.34 & 12.90 & 17.20 & 2.15 & 100 \\
\hline
\end{tabular}


WSRC-STI-2007-00386

Revision 0

This page intentionally left blank. 


\subsection{Selection of Impurities for Pu Glasses}

A quantity of approximately $14 \mathrm{~g}$ of $\mathrm{PuO}_{2}$ is available for this study, which will allow for fabrication of four glasses. The impurity concentrations to be used for these four glasses were chosen from the same matrix used for the surrogate glasses, as follows:

1. Pu35-03 - This set of impurities was chosen for its high concentration of metals.

2. Pu35-06 - This set of impurities was chosen for its high concentration of the anions $\mathrm{Cl}, \mathrm{F}$ and S, which are known to have low solubility in LaBS Glass.

3. Pu35-17 - This set of impurities was chosen for its high concentration of $\mathrm{Cl}$, which is known to have low solubility in LaBS glass.

4. Pu04-04 - This set of impurities was chosen for its relatively low concentration of impurities, and therefore higher concentration of $\mathrm{PuO}_{2}$.

The quantity of $\mathrm{HfO}_{2}$ included in these glasses that is not part of the frit will be replaced with $\mathrm{PuO}_{2}$. Fabrication and characterization of these four glasses will augment the results of the surrogate glasses with data for actual Pu-containing glasses. Note that there is an extra degree of conservatism in the surrogate glasses since $\mathrm{HfO}_{2}$ was substituted for $\mathrm{PuO}_{2}$ on a mass basis rather than a molar basis. 
WSRC-STI-2007-00386

Revision 0

This page intentionally left blank. 


\subsection{Pu Glass Compositions}

A letter ' $\mathrm{B}$ ' was appended to the glass identifiers to distinguish the glasses made with $\mathrm{PuO}_{2}$ from the surrogates (i.e., Pu35-03B, Pu35-06B, Pu35-17B and Pu04-04B). The compositions of these glasses are quite similar to their surrogate counterparts (in terms of $\mathrm{wt} \%$ oxides) except that the $\mathrm{HfO}_{2}$ used as a surrogate has been replaced by $\mathrm{PuO}_{2}$. The compositions of the four Pu glasses are given in Table 5-1.

Table 5-1. Target Glass Compositions for the Pu Glasses (in wt\%).

\begin{tabular}{|c|c|c|c|c|c|c|c|c|c|c|c|c|c|}
\hline Glass ID & $\mathrm{Cl}$ & $\mathbf{T a}_{2} \mathbf{O}_{5}$ & MgO & $\mathrm{K}_{2} \mathrm{O}$ & $\mathrm{Fe}_{2} \mathrm{O}_{3}$ & $\mathrm{Na}_{2} \mathrm{O}$ & $\bar{F}$ & $\mathrm{CaO}$ & 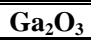 & $\mathrm{NiO}$ & $\overline{\mathrm{Cr}_{2} \mathrm{O}_{3}}$ & $\begin{array}{l}\mathrm{CuO} \\
\end{array}$ & $\mathrm{CSO}_{4}^{2-}$ \\
\hline Pu35-03B & 0.57 & 0.18 & 0.54 & 0.31 & 0.14 & 1.48 & 0.00 & 0.77 & 0.45 & 0.07 & 0.64 & 0.00 & 0.00 \\
\hline Pu35-06B & 0.60 & 0.10 & 0.91 & 0.27 & 0.97 & 0.80 & 0.48 & 0.29 & 0.00 & 0.28 & 0.22 & 0.00 & 0.17 \\
\hline Pu35-17B & 1.11 & 0.55 & 0.40 & 0.43 & 0.00 & 1.04 & 0.06 & 0.08 & 0.68 & 0.07 & 0.31 & 0.10 & 0.17 \\
\hline Pu04-04B & 0.00 & 0.00 & 0.08 & 0.07 & 0.08 & 0.08 & 0.00 & 0.08 & 0.00 & 0.08 & 0.09 & 0.07 & 0.00 \\
\hline Glass ID & C & PbO & $\mathrm{SeO}_{2}$ & $\mathrm{Cs}_{2} \mathrm{O}$ & $\mathrm{PuO}_{2}$ & $\mathrm{HfO}_{2}$ & $\mathbf{A l}_{2} \mathbf{O}_{3}$ & $\mathbf{B}_{2} \mathbf{O}_{3}$ & $\mathbf{G d}_{2} \mathbf{O}_{3}$ & $\mathbf{L a}_{2} \mathbf{O}_{3}$ & $\mathbf{N d}_{2} \mathbf{O}_{3}$ & $\mathrm{SiO}_{2}$ & SrO \\
\hline Pu35-03B & 0.00 & 0.00 & 0.00 & 0.06 & 8.79 & 6.02 & 8.60 & 11.18 & 11.61 & 16.34 & 12.90 & 17.20 & 2.15 \\
\hline Pu35-06B & 0.06 & 0.00 & 0.00 & 0.00 & 8.85 & 6.02 & 8.60 & 11.18 & 11.61 & 16.34 & 12.90 & 17.20 & 2.15 \\
\hline Pu35-17B & 0.06 & 0.00 & 0.00 & 0.00 & 8.93 & 6.02 & 8.60 & 11.18 & 11.61 & 16.34 & 12.90 & 17.20 & 2.15 \\
\hline Pu04-04B & 0.00 & 0.00 & 0.00 & 0.00 & 13.37 & 6.02 & 8.60 & 11.18 & 11.61 & 16.34 & 12.90 & 17.20 & 2.15 \\
\hline
\end{tabular}


WSRC-STI-2007-00386

Revision 0

This page intentionally left blank. 


\subsection{Summary}

Lanthanide borosilicate glass has been developed to support the Plutonium Immobilization Program. The glass is capable of immobilizing a high concentration of plutonium, however the relative tolerance of the glass composition to various impurities anticipated in the plutonium feed stream needs to be better characterized.

This report defined a compositional envelope for various impurities in the LaBS glass. A series of glasses will be fabricated and tested in the lab to evaluate the solubility of individual impurities as well as cumulative effects. The projected impurity types and concentrations in the plutonium feed streams anticipated for the Plutonium Immobilization Program were used to define a matrix of 60 test glass compositions. These glasses will use $\mathrm{HfO}_{2}$ as a surrogate for $\mathrm{PuO}_{2}$ to simplify laboratory work. Four additional glasses will contain actual $\mathrm{PuO}_{2}$ to augment the results of the surrogate testing. The glasses will be fabricated in the laboratory and evaluated through durability and crystallization testing. The results of this variability testing will be discussed in a separate report that will provide data to validate the acceptability of the compositional envelope defined here and/or provide additional compositional constraints for the plutonium feed materials. 
WSRC-STI-2007-00386

Revision 0

This page intentionally left blank. 
WSRC-STI-2007-00386

Revision 0

\subsection{References}

1. Vienna, J. D., D. L. Alexander, H. Li, M. J. Schweiger, D. K. Peeler and T. F. Meaker, "Plutonium Dioxide Dissolution in Glass," U.S. Department of Energy Report PNNL-11346, Pacific Northwest National Laboratory, Richland, WA (1996).

2. Meaker, T. F. and D. K. Peeler, "Solubility of Independent Plutonium Bearing Feed Streams in a Hf-Based LaBS Frit, contained in: Plutonium Immobilization: The Glass Option - A Compendium of Reports and Presentations," U.S. Department of Energy Report WSRC-RP-9700902, Westinghouse Savannah River Company, Aiken, SC (1997).

3. Smith, M. E. and G. L. Hovis, "Phase 1 Can-in-Canister Cold Pour Tests for the Plutonium Immobilization Project,” U.S. Department of Energy Report WSRC-TR-99-337, Westinghouse Savannah River Company, Aiken, SC (1999).

4. Smith, M. E., G. L. Hovis and E. L. Hamilton, "Phase 2 Can-in-Canister Cold Pour Tests for the Plutonium Immobilization Project,” U.S. Department of Energy Report WSRC-TR-2000-408, Westinghouse Savannah River Company, Aiken, SC (2000).

5. Eisele, D. P., “Technical Task Request: Glass Formulation and Performance Testing to Support Pu Disposition,” U.S. Department of Energy Report M09A-SRNL-010, Washington Savannah River Company, Aiken, SC (2007).

6. Marra, J. C., K. M. Fox and E. N. Hoffman, "Task Technical and QA Plan: Glass Formulation and Performance Testing to Support Pu Disposition," U.S. Department of Energy Report WSRCSTI-2007-00076, Washington Savannah River Company, Aiken, SC (2007).

7. Moore, E. N. and J. S. Allender, "Projected Characteristics of Nominal Feeds to Plutonium Disposition Project,” U.S. Department of Energy Report SRNL-OPD-2007-00008, Washington Savannah River Company, Aiken, SC (2007).

8. Cornel, J. A., Experiments with Mixtures: Designs, Models, and the Analysis of Mixture Data, John Wiley and Sons, New York (2002).

9. JMP $^{\mathrm{TM}}$, Ver. 6.0.2, [Computer Software] SAS Institute Inc., Cary, NC (2005).

10. SAS Institute Inc., JMP Design of Experiments, Release 6, SAS Institute, Inc., Cary, NC (2005).

11. Marra, J. C., D. K. Peeler and C. M. Jantzen, "Development of Alternative Glass Formulations for Vitrification of Excess Plutonium," U.S. Department of Energy Report WSRCTR-2006-00031, Revision 0, Washington Savannah River Company, Aiken, SC (2006).

12. Marra, J. C., “Throughput Basis for the Plutonium Vitrification Facility,” U.S. Department of Energy Report SRT-RPP-2004-00037, Washington Savannah River Company, Aiken, SC (2004). 
WSRC-STI-2007-00386

Revision 0

This page intentionally left blank. 
WSRC-STI-2007-00386

Revision 0

\section{Appendix}

Additional Data Supporting the Development of the Impurity Test Matrix 
Table A1. Linear Correlations Among Pairs of Elements for the Test Matrix

\begin{tabular}{|c|c|c|c|c|c|c|c|c|c|c|c|c|c|c|c|c|c|}
\hline & $\overline{C \mathrm{Cl}}$ & $\overline{\mathbf{T a}}$ & $\overline{\mathrm{Mg}}$ & $\bar{K}$ & $\overline{\mathrm{Fe}}$ & $\mathrm{Na}$ & $\bar{F}$ & $\overline{\mathrm{Ca}}$ & $\overline{\mathrm{Ga}}$ & $\mathrm{Ni}$ & $\overline{\mathrm{Cr}}$ & $\overline{\mathrm{Cu}}$ & $\overline{\mathrm{S}}$ & $\overline{C \mathrm{C}}$ & $\overline{\mathbf{P b}}$ & Se & Cs \\
\hline $\mathrm{Cl}$ & 1.0000 & 0.1293 & 0.0161 & .0682 & .2229 & .1330 & .0195 & .4171 & .0833 & .1310 & 0.3218 & 0.2213 & 2594 & 0.2128 & .2360 & .0961 & 026 \\
\hline Ta & 0.1293 & 1.0000 & 713 & 0.0029 & .1733 & 692 & -0.0785 & 0303 & & & 93 & & 0.0533 & 0.0795 & 922 & 662 & \\
\hline $\mathrm{Mg}$ & 0.0161 & -0.0713 & 1.0000 & 0.0384 & 0.0510 & -0.0765 & 0.1162 & 0.1001 & 0.0013 & 521 & 0.1 & 05 & -0.0266 & -0.0038 & 88 & 731 & 0755 \\
\hline K & & 29 & & & & & & & & & & & 279 & 485 & & 843 & \\
\hline $\mathbf{F e}$ & 0.2229 & -0.1733 & 0.0510 & 0.0648 & 1.0000 & 0.2911 & -0.0278 & 0.2060 & -0.1469 & 0.3941 & 0.1897 & -0.0313 & 0.1911 & 0.1638 & 0.0020 & \begin{tabular}{|l|}
-0.0082 \\
\end{tabular} & 0.0881 \\
\hline $\mathrm{Na}$ & 30 & .0692 & 65 & 0.0768 & 11 & 1.0000 & 309 & 96 & & 207 & -0.1085 & & 169 & 0.1582 & 989 & 066 & 405 \\
\hline $\mathbf{F}$ & -0.0195 & -0.0785 & 62 & -0.1571 & 0.0278 & 309 & 1.0000 & 0.0064 & 21 & 23 & 013 & 59 & -0.0338 & 0.0962 & 65 & 884 & -0.0039 \\
\hline $\mathbf{C a}$ & 0.4171 & -0.0303 & 0.1001 & 0.1886 & 0.2060 & 0.1996 & -0.0064 & 1.0000 & -0.0 & 0.1411 & 0.0331 & -0.0 & 0.1623 & 0.1989 & 531 & 579 & 0.1728 \\
\hline Ga & 0.0833 & -0.0128 & & 0.3018 & .1469 & 290 & 0.0921 & -0.0112 & & 242 & 489 & & 172 & 0.0384 & 385 & 057 & 0.0929 \\
\hline $\mathrm{Ni}$ & 0.1310 & 0.2109 & 221 & -0.0859 & 0.3941 & 0.2207 & 0.0323 & 0.1411 & 0.1242 & 1.0000 & 0.1590 & 0.0 & 0.2486 & 0.2444 & 113 & 677 & 1786 \\
\hline $\mathrm{Cr}$ & 3218 & 293 & 31 & \begin{tabular}{|l|}
-0.0149 \\
\end{tabular} & 897 & 85 & 3013 & 331 & & 590 & 000 & & 0.1800 & 0.1297 & & 778 & 119 \\
\hline $\mathbf{C u}$ & 0.2213 & 0.2652 & 805 & \begin{tabular}{|l|}
0.1444 \\
\end{tabular} & -0.0313 & 0.0136 & 0.1059 & -0.0264 & 20 & 0.0480 & 0.1843 & 1.0000 & 0.1896 & 0.1389 & 0.1345 & 0.0433 & -0.0844 \\
\hline $\mathrm{S}$ & 0.2594 & 0.0533 & -0.0266 & 0.0279 & 0.1911 & 0.1169 & -0.0338 & 23 & 72 & 486 & 0.1800 & 96 & 1.0000 & 0.6901 & 05 & 222 & 0.7222 \\
\hline $\mathrm{C}$ & 0.2128 & 0.0795 & \begin{tabular}{|l|}
-0.0038 \\
\end{tabular} & \begin{tabular}{|l|}
-0.0485 \\
\end{tabular} & 0.1638 & 0.1582 & 0.0962 & 0.1989 & 0.0384 & 0.2444 & 0.1297 & 0.1 & 0.6901 & 1.0000 & 0.6932 & 211 & 0.6211 \\
\hline $\mathbf{P b}$ & 0.2360 & 0.0922 & 0.0288 & \begin{tabular}{|l|}
-0.0903 \\
\end{tabular} & 0.0020 & -0.0989 & 0.0165 & 0.1531 & 0.0385 & 0.1113 & 0.1596 & 0.1345 & 0.7105 & 0.6932 & 1.0000 & 0.7785 & 0.7105 \\
\hline Se & 0.0961 & 0.0662 & & \begin{tabular}{|l|}
-0.0843 \\
\end{tabular} & -0.0082 & -0.0066 & 0.0884 & 0.0579 & & 0.1677 & 0.1778 & & 0.7222 & 0.6211 & & 1.0000 & 0.6528 \\
\hline Cs & 0.0261 & -0.0662 & -0.0755 & -0.0653 & 0.0881 & -0.0405 & -0.0039 & 0.1728 & 0.0929 & 0.1786 & 0.0119 & -0.0844 & 0.7222 & 0.6211 & 0.7105 & 0.6528 & 1.0000 \\
\hline
\end{tabular}




\section{Exhibit A1. Scatter plot Matrix for Test Points}

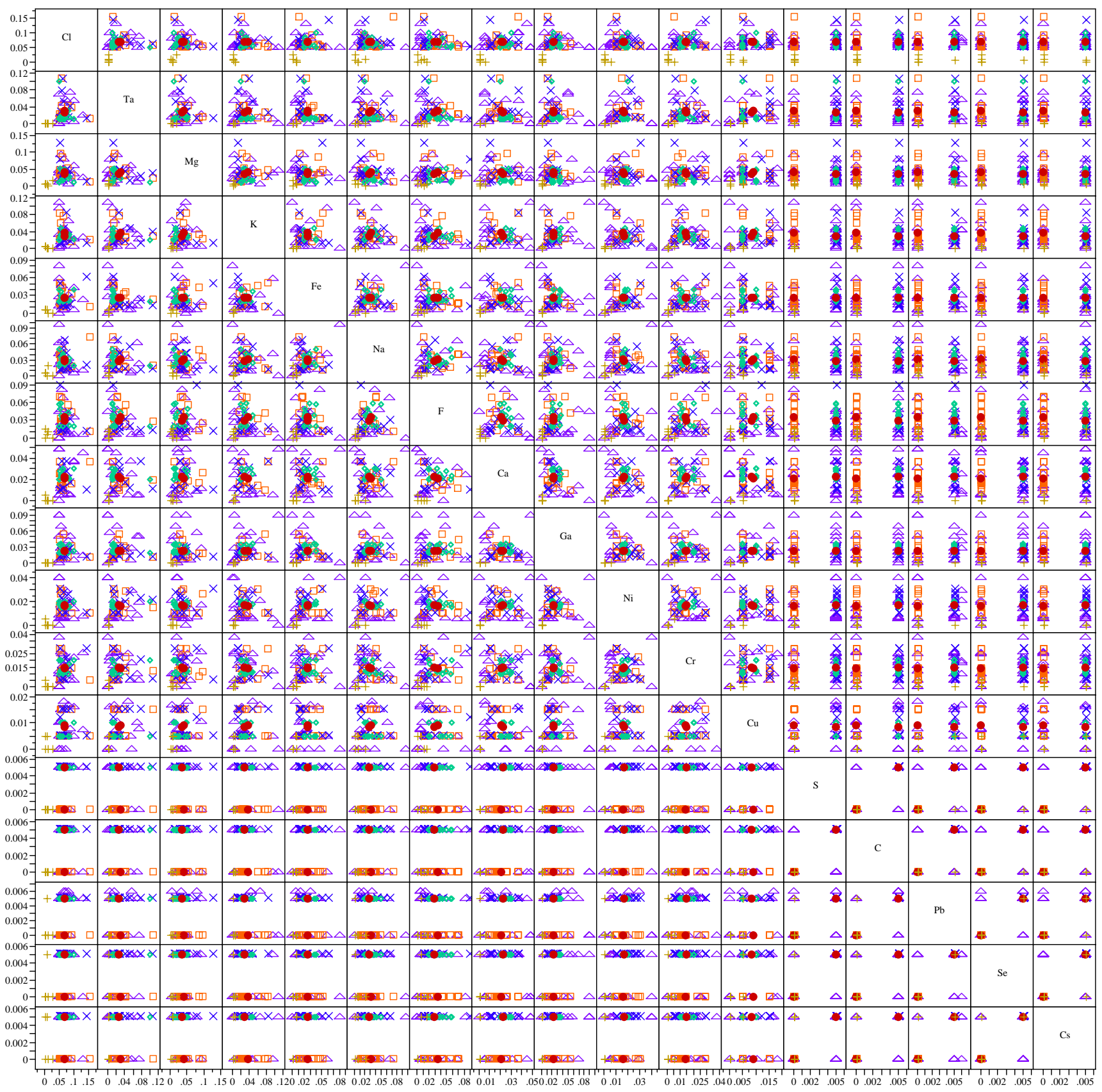


Exhibit A2. Distribution of Individual Impurity Elements

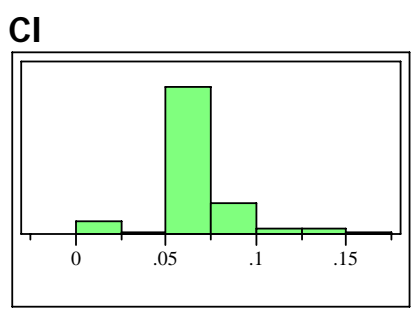

Ta

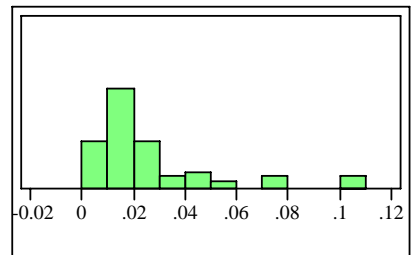

Mg

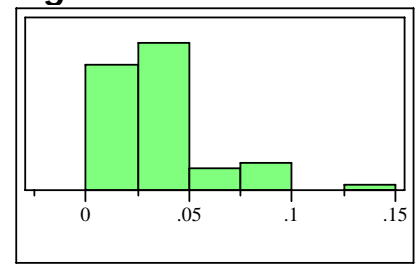

$\mathbf{K}$

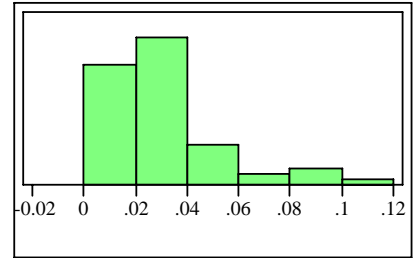

Fe

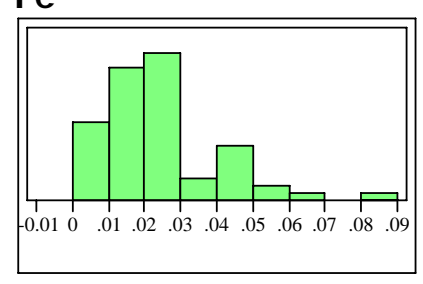

$\mathrm{Na}$

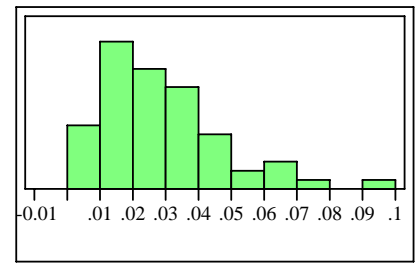

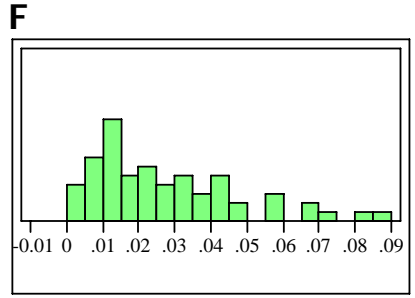

Ca

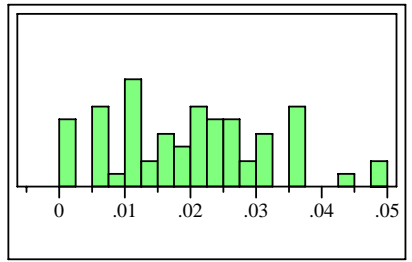

Ga

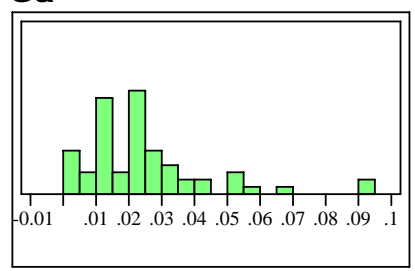

$\mathrm{Ni}$

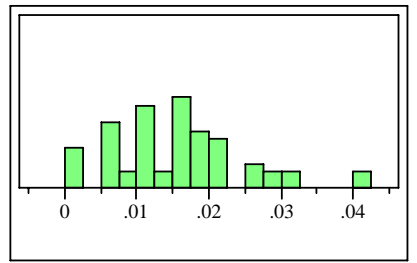

$\mathrm{Cr}$

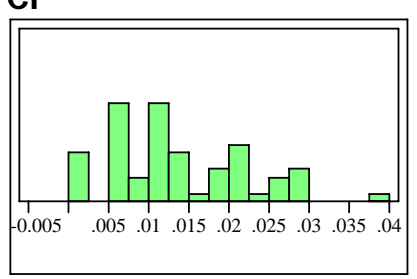

Cu

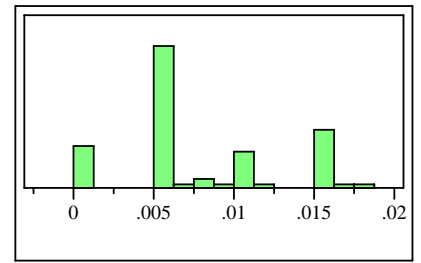

$\mathbf{S}$

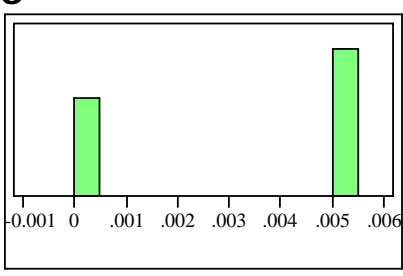

C

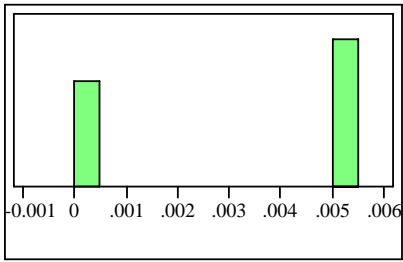

$\mathbf{P b}$

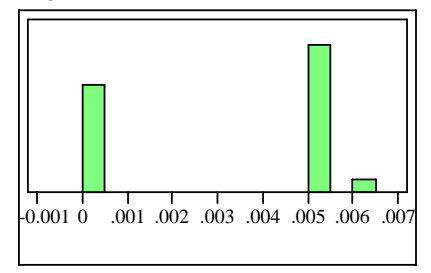

Se

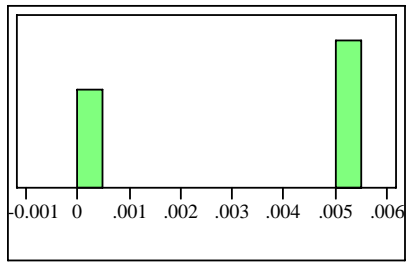

Cs

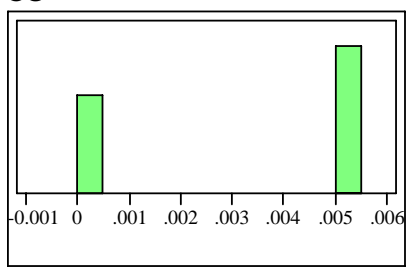

